\title{
DESTRUCTION OF VOLATILE ORGANIC COMPOUNDS BY CATALYTIC OXIDATION
}

\author{
Alice Oana Rusu*, Emil Dumitriu \\ Technical University of Iasi, Laboratory of Catalysis, Mangeron Street 71, 700050, Iasi, Romania
}

\begin{abstract}
Volatile organic compounds, emitted by a lot of sources, particularly from gasoline engines of automobiles, are air pollutants that give rise to deleterious health and environmental effects. Total catalytic oxidation is an attractive method in controlling these emissions due the great amounts of energy saved, by the moderate temperature involved. For wide implementation of catalytic combustion, thermally, mechanically and chemically stable catalysts are required. The paper is a short reviewing of the available catalysts and also of the new innovations concerning either enhance of their performances or new better formulations.
\end{abstract}

Keywords: volatile organic compounds, catalytic oxidation, catalyst life

\section{What are VOCs and why have to eliminate them}

VOCs are everywhere: at homes, at dry cleaning units, at food processors, at petroleum refineries, at airports and automobile service stations, at electronics and chemical plants, at print and paint shops etc. VOCs are those chemicals that exposed to air volatilize readily. So, these compounds contribute to air pollution by their vapour and to water and soil pollution by that fraction which can be carried deep into the soil by rainwater and melting snow. This work studies VOCs only from the viewpoint of the air pollution.

\subsection{Environment and VOCs}

VOCs are dangerous for humans, fauna and flora. Firstly, these compounds have been proved to cause a variety of adverse health effects (Minnesota Department of Health, 2003, Regional Environmental Assessments, 2002; U.S. EPA, 2003). Generally, allergic skin reaction, dizziness, headaches, eye and respiratory tract irritation, coughing, visual disorders, memory impairment, confusion, anemia and fatigue are some of the symptoms associated with short-term exposure. Kidney, liver, brain damage, cardiac sensitization reactions and also damage to the nervous, reproductive and immune systems are caused by long-term exposure. VOCs are also "endocrine impostors". Some are

\footnotetext{
*Author to whom all correspondence should be addressed: e-mail: oanarush@yahoo.com
} 
also known or suspected of causing cancer. Also, the natural plant processes can be destroyed or interrupted by some organic volatile compounds. In the atmosphere these chemicals are transformed in other compounds even more dangerous for humans, fauna and flora. The ground level or "bad" ozone, a key ingredient of urban smog, is created by a chemical reaction between oxides of nitrogen (NOx) and volatile organic compounds in the presence of sunlight. Repeated exposure to ozone pollution may cause a variety of health problems (Clean Air Counts, 2003); ozone also reduces the growth rate of trees and agricultural production. VOCs participate in the greenhouse effect, acid rains and stratospheric or "good" ozone depletion, which are serious environmental problems (Avila et al., 1998). Consequently, VOCs are a great group of air pollutants and our duty is to eliminate them from being released. For this reason, firstly, we must know who are they and which are their sources.

\subsection{VOCs and their sources}

The USA Environmental Protection Agency (EPA) gave the following definition for VOCs - any compound of carbon, excluding carbon monoxide, carbon dioxide, carbonic acid, metallic carbides or carbonates, and ammonium carbonate, which participates in atmospheric photochemical reactions. This includes any organic compound other than the compounds that have been determined to have negligible photochemical reactivity (e.g. methane, ethane, methylene chloride...). According to this definition a wide variety of organic compounds, such as aliphatic, aromatic and chlorinated hydrocarbons, aldehydes, ketones, esters, organic acids and alcohols can be considered as VOC (see the complete list in (Ron Joseph \& Associates, 2000)).

Emissions of VOCs could appear from natural sources, but most VOCs emissions result from man-made sources. Approximately 235 millions tonnes of VOCs are released per year into the atmosphere from anthropogenic sources (Guenther et al., 1995) and that is because there are thousands of different VOCs produced and used in our daily lives. In the USA ca. $40 \%$ of the VOCs emissions are released from transportation activities and the remaining 60\% result from stationary sources. The last sources are about equally divided between fuel combustion, industrial manufacturing and solvent emissions (Horsley, 1993) and might be interior or exterior sources. Some examples of commercial operations that produce volatile organic compounds emissions are: chemical plants, petroleum refineries, pharmaceutical plants, automobile manufacturers, airplane manufacturers, food manufacturers, textiles manufacturers, printing plants, can coating plants, wire enameling plants, electronic component plants, painting facilities, wood stoves. In all these manufacturing processes organic materials are present as petroleum derivatives, chemicals, solvents, pigments, release agents, coatings, paints, adhesives. Usually they leave the plant in a form of a gaseous effluent that contains low concentrations of organics and that is vented into the atmosphere. Concerning household, some products that contain volatile organic compounds and pollutes the indoor air are: paints, paint strippers, lacquers, solvents, wood preservatives, 
aerosol sprays (cosmetics), cleaners and disinfectants, moth repellents and pesticides, air fresheners, stored fuels and automotive products, hobby supplies, dry-cleaned clothing, building materials and furnishings, office equipment such as copiers and printers, correction fluids and carbonless copy paper, permanent markers, photographic solutions and so forth (Regional Environmental Assessments, 2002; U.S. EPA, 2003; Minnesota Department of Health, 2003).

\subsection{Measures against VOCs emissions}

The progressive increase of VOCs emissions, as well as of the information about their harmful effects, determined environmental legislation of the worldwide to introduce more stringent regulations to control their release (Clean Air Counts, 2003; U.S. EPA, 2003;). In United States of America, the champion in this fight against the environment pollution, The Clean Air Act Amendments of 1990 calls for a $90 \%$ reduction in emissions of 189 toxic chemicals, $70 \%$ of them VOCs, over the next nine years (Parkinson, 1991). For that call, USA Environmental Protection Agency (EPA), which has been working for a cleaner and healthier environment for the American people for 30 years, states and cities implemented programs to further reduce emissions from stationary and mobile sources. Some solutions are green technologies, cleaner car and fuel, gas station using special nozzles at the pumps to recapture vapour, vehicle inspection programs, etc. At the beginning of 1997 there are over 6000 systems operating throughout the world controlling VOC emissions (Anguil Environmental Systems Inc.).

The methods used for decreasing emissions of VOCs can be divided (Dumitriu and Hulea, 1997) in: optimization of the process by implementation of "green technologies "and cleaning of flue gases. Many different techniques, which can be the "end-of-the-pipe" control technologies for VOCs abatement, are available (GlobalSpec Inc., 2003; Haslego, 2002; Uberoi, 2000) They use either the capture of the pollutants or/and their destruction. When products recovery is desired capture techniques like as condensation, absorption and adsorption are required. Contaminants can be destroyed by a flame (incineration) or by a microorganism (biodegradation). The selection of the most appropriate method will depend on following criteria: desired control efficiency, contaminant properties (e.g. stickiness, volatility, molecular weight, $\mathrm{pH}$, solubility in water or other solvents), air stream properties (concentration, flow rate, heat content, vapour pressure, temperature, particulate matter loading, moisture content), safety issues (flammability, explosivity), value of recovered material etc.

Among the technologies mentioned above for VOCs abatement the most widely implemented is the incineration (oxidation). Destruction efficiency of this method can achieve more than 99, 99\% depending on the type of the system (GlobalSpec Inc., 2003). There are two forms of incineration: thermal oxidation and catalytic oxidation. 


\section{Catalytic oxidation versus thermal oxidation as methods for reduction of VOCs emissions}

By total oxidation, VOCs molecules are transformed into $\mathrm{CO}_{2}$ and $\mathrm{H}_{2} \mathrm{O}$. For break apart VOCs molecules and oxidize them to carbon dioxide and water, that means for overcome the activation energy of this reaction, a certain amount of energy is required, so the temperature of the air stream containing VOCs molecules have to be raised to a certain point - typically in excess of $760^{\circ} \mathrm{C}$ (Cooley, 2002). This is a thermal oxidation and it occurs in a thermal oxidizer (Auckland Regional Council, 2000; Anguil Environmental Systems Inc.) involving a high temperature system (e.g. direct flames, plasma torch and indirectly heated ceramic bed oxidizer). It is important to know that this reaction is an exothermic one, so the resulted heat could be used to preheat the incoming exhaust. Thus, the input energy required is less and fuel costs are reduced. The heat recovery may be achieved by a recuperative or a regenerative system. In the first the waste heat is transferred to the process air through a surface (air-toair exchanger, for example) as long as a temperature gradient exists between the two fluids. In the second one the waste heat is transferred to the surface of a ceramic stoneware over time, after which the incoming air passing over the same surface absorbs the heat.

Another way to reduce the input energy and thus the costs with fuel is the catalytic oxidation. In this case, the same reaction occurs into a catalyst bed and the activation energy barrier is lower, so the temperature required is significantly lower - typically starting at 205 to $260{ }^{\circ} \mathrm{C}$ (Cooley, 2002). In addition, the catalyst facilitates a faster reaction in smaller volume equipment.

Various catalytic technologies of incineration have been developed by different companies. For example, Anguil Environmental Systems Inc. is a leader concerning the technologies used in controlling air pollution (Anguil Environmental Systems Inc.). They make thermal and catalytic incinerators, also.

Concerning the technological aspects, both thermal oxidation and catalytic oxidation have limitations. In choosing the right technology, a careful review of all the aspects needs. In (Auckland Regional Council, 2000; Uberoi, 2000) are described the "suitable incinerator applications" and "recommended performance and design criteria for incinerators". Factors, which must be careful assessed when VOCs abatement by catalytic oxidation occurs, are (Cooley, 2002): the lower explosive limit - for safety considerations the gas stream (inlet), which is introduced with the combustion air, must have its concentration less than $25 \%$ of the lower explosive limit (LEL), the flow rate - typical system capacities range from 2,8 to 283 cubic meters per minute and VOCs concentration - catalytic oxidation typically has environmental applications for VOCs concentrations "from a few hundred to a few thousand parts per million (ppm) but, is the preferred technology for "relatively low VOCs concentrations $(\sim 10$ ppm v)". 
Do not forget the three " $T$ ' $s$ " of combustion: turbulence, time and temperature.

Catalytic oxidation has been applied for odour control (Hermia, 1993) and treatment of emissions containing evaporated solvents (Vigneron, 1996). Also, a technology for treatment of very low concentration VOCs in indoor air is being sought (O'Malley and Hodnett, 1999).

A great advantage of catalytic oxidation is that it can be also used for mobile sources. It is known that automotive exhaust gases formed in the gasoline engines contain many environmentally harmful compounds, as a result of incomplete combustion, like carbon monoxide $(\mathrm{CO})$, hydrocarbons $(\mathrm{HC})$ and $\mathrm{NO}_{\mathrm{x}}$. The developing of an interesting device called catalytic converter, which treats the exhaust gas before it leaves the car, is a real progress (Nice, 2003). This device converts the three regulated emissions - CO, VOCs and $\mathrm{NO}_{\mathrm{x}}$ (it is known like Three Way Catalyst- TWC) at $\mathrm{CO}_{2}, \mathrm{H}_{2} \mathrm{O}$ and $\mathrm{N}_{2}$. TWCs have been fitted to cars since the 1970s (Heck and Farrauto, 2001) and due to the increased demand for low-emission vehicles (see Euro Standard) (Vehicle Certification Agency, 2002), most automobiles are now supplied with a three-way catalytic converter ( $85 \%$ of all new cars world wide are fitted with TWC). There is a short history of the evolution of the converters since 1976 up to now (Dumitriu and Hulea, 1997).

The application of catalytic oxidation like a method for emission control is described in the literature in several review articles (Prasad, 1984; Nakajima, 1991). The moderate temperatures involved into a catalytic oxidizer cause, besides the attractive saved energy, the possibility to use heat exchangers made by common alloys (John Zink Company, 1991) and also a higher selectivity to $\mathrm{CO}_{2}$ and $\mathrm{H}_{2} \mathrm{O}$; harmful by-products, such as dioxin and nitrogen oxides, which are formed into thermal oxidizers (Ramachandran, 1996) (involve high temperatures), are not generated. It has been reported that formation of partially oxidized intermediates, much toxic than the originals could occur (Lintz and Wittstock, 2001).

The economic factors, which have made catalytic oxidation an attractive method, are in competition with some negative factors such as the price of the catalyst and its lifetime. The last factor is depicted in the paragraph 3.3 (Catalyst life).

\section{About catalytic oxidizers and catalytic systems}

\subsection{The catalytic oxidizer}

A catalytic oxidizer is similar in design to a recuperative one (Auckland Regional Council, 2000; Anguil Environmental Systems Inc.), except that the oxidation of VOCs occurs into the catalyst bed instead into the open flames. The air containing VOCs is ducted to the catalytic system passing through a heat exchanger for preheating. Into the burner chamber the air is heated to the specific VOC catalyst reaction temperature. The heat released due to oxidation 
process preheats the incoming exhaust. The difference between the thermal oxidizer and the catalytic one is that the catalyst allows the same VOC destruction at considerably lower temperature, saving fuel costs. The scheme of a catalytic oxidizer made by Anguil Environmental Systems Inc. is given in Fig. 1.

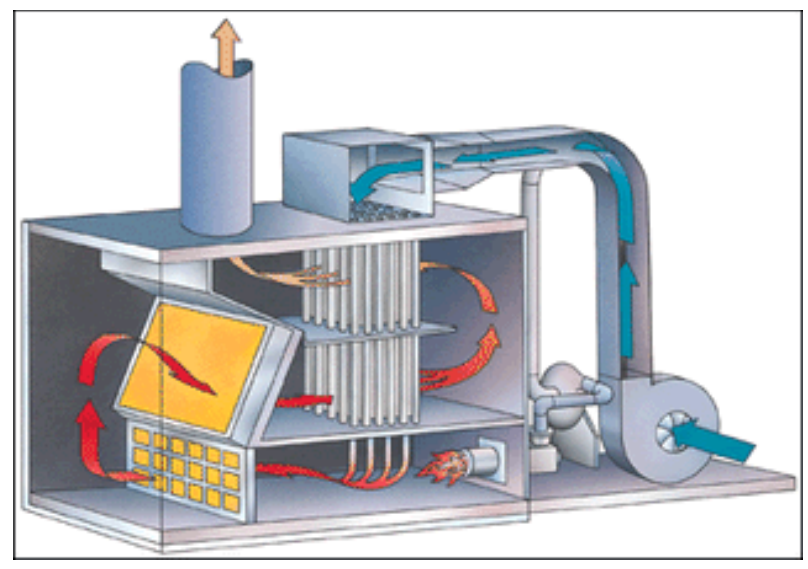

Fig. 1. Catalytic oxidizer (Anguil Environmental Systems Inc.).

\subsection{The configuration of the catalytic system}

A typical catalytic system is composed of a catalytic active material, finely dispersed across an extended surface provided by a mechanical support, which has been previously washcoated with a highly porous material (Cooley, 2002; John Zink Company, 1991). The active material presents the "sites" where the reaction between oxygen and VOCs occurs. Noble metals and certain metal oxides are the most active materials for VOCs oxidation (Lahousse et al., 1998b). The washcoat with its high surface area maximizes the number of active sites available to the reactants and it is called "the support material". The physical structure and the mechanical integrity of the ensemble are provided by the "mechanical support", which takes several forms such as pellet or monolith honeycomb, by metal (stainless steel) or ceramic. Dumitriu and Hulea (1997) have made a depiction of all these systems. Typically, manufacturers employ the ceramic honeycomb, with a critical design in achieving maximum destruction removal efficiency (DRE) (Cooley, 2002). In Fig. 2 it is presented the way of distribution of the washcoat on the monolith walls.

\subsection{Catalyst life}

Limitations of catalytic oxidation are affined with the limitation of the catalytic system: catalyst life and catalyst cost.

Theoretically, the catalyst is ageless. In practice its life is reduced (Cooley, 2002). It is known that the catalytic activity of a catalyst in VOCs complete oxidation studies is evaluated by tracing the ignition (light-off) curves 
("VOC conversion versus reaction temperature") (John Zink Company, 1991; Paulis, 2000). After some period of operation this curve may indicate a loss of activity (deactivation). The three main reasons for catalyst deactivation are poisoning, fouling and thermal deactivation, which can act alone or in combination. The followings are for explain away the reasons for these phenomena.

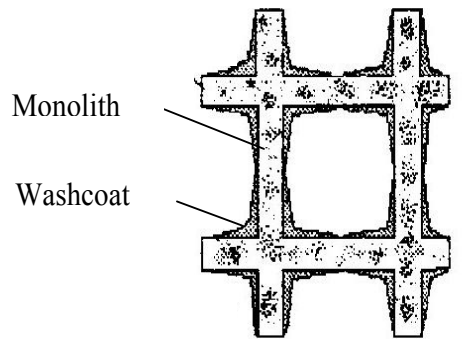

Fig. 2. Monolith ceramic - section (Dumitriu and Hulea, 1997).

The active sites of a catalyst could react with a second chemical and if the catalytic activity is enhanced, the phenomenon is known as doping, if decreased, as poisoning (Thomas and Thomas, 1967). There are some chemical species contained in exhaust gases, which are considered like poisons: halogens, silicones, phosphorus, sulphur, mercury, lead and cadmium (Cooley, 2002; John Zink Company, 1991). When chlorinated compounds are converted over catalysts (Dumitriu and Hulea, 1997; Sinquin et al., 2001) chlorine may block the active sites and $\mathrm{HCl}$ may react with the carrier and can provoke its crystalline structure collapse, or metal-chlorine species may be vaporized (Spivey and Butt, 1992). A VOC stream containing over $10 \mathrm{ppm}$ of halogenated compounds degrades the activity of a typical catalyst by up to $43 \%$ (Süd-Chemie Prototech; John Zink Company, 1991). There are some reviews (Spivey and Butt, 1992; Wilde and Anders, 1994) about the effects of chlorinated compounds on different catalysts, noble metals and metal oxides. Also, there are some reports (Chatterjee, 1992), which evidenced that zeolites are more efficient catalysts for chlorinated hydrocarbons oxidation. A good catalyst for chlorinated compounds oxidation must not be affected by the above mentioned degradation phenomena. In addition, it must also limit the formation of hazardous volatile organics like phosgene, chlorinated dioxins or dibenzofurans and inorganic like metal chlorides or oxychloride (Sinquin et al., 2001; Weber et al., 2001). Now, catalyst suppliers offer suchlike catalysts (John Zink Company, 1991). When the organics contain silicone, phosphorus or sulphur their oxides are formed, which cover the active sites decreasing the catalytic activity. Therefore the researchers are looking for catalyst formulations which display a lower affinity for these 
metallic oxides.

When the active sites and/or the pores of the catalyst are blocked by a material which is deposited on it is said that the fooling of the catalyst occurs (Bartholomew, 1984). The most common foulant is coke (carbonaceous deposits) (Biloen et al., 1977). It is formed by undesired reactions of the organic compounds over the catalyst and its chemical nature varies widely, from graphitic carbon to condensed polymers. Zeolites are the catalysts often compliant with suchlike deactivation.

Catalysts can operate at reasonably high temperatures. In time, thermal deactivation can occurs (Trimm, 1991). This is a more problem, in this case the deactivation being irreversible. The high temperature may induce solid state reactions between components of the catalyst; if the active material reacts with the carrier formation of compounds of lower or negligible activities occurs. At high temperature crystals grow or components of the catalyst recrystallize, such processes leading to a loss of surface area. This last form of deactivation is called sintering and this involves a redistribution of a material in the solid state in order to decrease the surface energy. The third form of thermal deactivation is represented by catalyst volatilization. It is important to develop low-temperature catalysts, chiefly one of the aims of the researchers is minimization the cold-start period.

Thus, the implementation of catalysts poses some problems, which are challenges for researchers. Besides a great activity (if it is possible even during the cold start-up phase), a good catalyst have to be resistant to the varying temperature conditions and to poisonings, and last but not the least, it must have a low-cost.

The objective of this work is reviewing some studies made on different catalysts on VOCs oxidation, dwelling on innovations with positive consequences concerning the catalytic activity, cost and the durability of the catalyst.

\section{Catalytic systems used on VOCs oxidation}

\subsection{Carriers used on VOCs oxidation}

The carrier must be a microporous refractory with a high surface area (between 150 and $300 \mathrm{~m}^{2} / \mathrm{g}$ of support) (Cooley, 2002) able to attach the active phase and attract reactants via adsorption. Some of the suchlike materials used on VOCs oxidation are depicted further.

The most commonly used carrier for the active phases for VOCs destruction is $\boldsymbol{\gamma}-\boldsymbol{A l}_{2} \boldsymbol{O}_{3}$ (alumina) (Müller, 1993). $\gamma$-Alumina may have a surface area of 100 to 200 square meters per gram $\left(\mathrm{m}^{2} / \mathrm{g}\right)$ (Dumitriu and Hulea, 1997). It is known that at elevated temperatures its crystal structure changes by sintering, the most thermodynamically stable phase being $\alpha-\mathrm{Al}_{2} \mathrm{O}_{3}$, with a surface area of $1-5 \mathrm{~m}^{2} / \mathrm{g}$. Besides the diminution of the surface area, these "macroscopic movements of the substrate" are accompanied by a decrease in the mechanical 
strength of the catalyst (Shkrabina et al. 1995). At the same time, the metal particles dispersed on alumina can stick together (Miyoshi et al., 1989) or/and can be encapsulated into the carrier (process known as the"earthquake phenomena") (Tucci, 1982). Thus, the metal surface area decreases and the catalytic activity is reduced. Moreover, it has been observed that this phase transformation of $\gamma-\mathrm{Al}_{2} \mathrm{O}_{3}$ into $\alpha-\mathrm{Al}_{2} \mathrm{O}_{3}$ is accelerated by the active phase such as Pt (Burtin et al., 1987), and oxides of metals such as Mn, Fe, Ni, Mo, Co, V and $\mathrm{Cu}$ (Peiyan et al., 1995; Ozawa et al., 1996a), which due to their higher concentrations have a stronger effect than noble metals. Ferrandon made a review (Ferrandon, 2001) of the ions ( $\mathrm{Zr}, \mathrm{Ti}, \mathrm{La}, \mathrm{Ce}, \mathrm{Ba}, \mathrm{Sr}, \mathrm{Si}, \mathrm{Sn}, \mathrm{Mg}, \mathrm{Ca}$ ), which doping into the alumina stabilize it and claimed that by addition of a stabiliser the sintering effects can be inhibited. One of the best additives for inhibiting the $\mathrm{Al}_{2} \mathrm{O}_{3}$ appears to be La (Burtin et al., 1987; Peiyan et al., 1995), especially when active species are supported on it (Ozawa et al., 1996b; Shkrabina et al., 1995;). A suchlike alumina combined with such oxides is used as washcoat for three-way catalysts (Trovarelli, 1996). Concerning the mechanism of stabilization and the other positive effects of La doping, Ferrandon made a review (Ferrandon, 2001) and has concluded that responsibles are the perovskite $\mathrm{LaAlO}_{3}$ and the lanthanum- $\beta$-alumina.

The other disadvantage of alumina is its low resistance against hydrogen chloride and chlorine (Kulażyński et al., 2002). This is a reason to search for new support materials that are not affected by these products. Above it was already mentioned that now exists suchlike materials. $\mathrm{TiO}_{2}-\mathrm{SiO}_{2}$ exhibits a high resistance against $\mathrm{HCl}$ (Kulażyński et al., 2002) and Sud-Chemie Prototech's (Süd-Chemie Prototech) offers specially formulated washcoat and supports which prevent halogen attack and remain stable.

Due its thermal and chemical stability, coupled with acid-base properties and oxygen storage capacity (Cimino et al., 2002), $\mathbf{Z r O}_{2}$ is meeting with increasing interest in the field of heterogeneous catalysis such as active phase or support/promoter. By supporting noble metals (Fuji et al., 1987; Moles, 2001), metal oxides (Fuji et al, 1987; Ismajilov et al., 1998) and perovskites on zirconia are obtained good catalysts for oxidation. By introduction of zirconia in the ceria lattice (Bozo et al., 2000) a higher mobility of surface and bulk lattice oxygen species is obtained so that methane can be oxidized (its conversion starts at $400^{\circ} \mathrm{C}$ and is complete at $800^{\circ} \mathrm{C}$ ). Obviously, when platinum was dispersed on this carrier a better activity versus methane oxidation was achieved (conversion starts at $200^{\circ} \mathrm{C}$ ).

Due its properties, $\mathbf{S n O}_{2}$ can be used like support and like active phase in VOCs catalytic oxidation, also. It has been reported that by doping $\mathrm{SnO}_{2}$ with $\mathrm{SO}_{4}{ }^{2-}$ anions (Ishikawa et al., 1994) it is obtained a good carrier for $\mathrm{Pd}$ on methane oxidation, because of the superacid sites, which impede the sintering, and of the more active oxygen species.

Niobia is another metal oxide used like support in VOCs oxidation, it supporting metals and vanadium oxide (Huuhtanen and Andersson, 1993).

Applications of zeolites in environmental catalysis are described in 
recently published review articles (e.g., Iwamoto, 1994). The most used for catalytic combustion are metal-containing zeolites (Kucherov et al., 1998). Because their well-defined framework and their acidic properties, which can be controlled, zeolites present some advantages as compared to the other supports, chiefly they have catalytic activity, also. Zeolites can control the type and the particle sizes of the metal supported on them (Kühl, 1999) and can provide high dispersion for the active components (Kalantar Neyestanaki et al., 2000). The intracrystalline space of zeolites has a main role in process kinetics, also (Botavina et al., 2001). Zeolites can be used for a wide range of fuel-air ratios and need lower operating temperatures of VOCs oxidation. Total conversion can be achieved between $140^{\circ} \mathrm{C}$ and $360^{\circ} \mathrm{C}$, depending on the nature of the organic compound (Kullavanijaya et al., 2000; Lahousse et al., 1998). During VOCs oxidation carbonaceous deposits (coke) are formed inside the pores and on the outer surface of zeolites (Derouane, 1985). This leads to their deactivation.

There are very few reports on the use of pillared interlayered clays (PILCS) on the complete oxidation of VOCs. These are high surface area microporous materials with the diameter and acidity of the porous structure comparable to that of zeolites (Gil et al., 1996). Sometimes, mesoporosity could be also formed. The Brőnsted acidity and the specific surface area of PILCs contributed to a better catalytic performance of the transition metal species, suchlike Al and Cr (Gil et al., 1998) and of the noble metals, like Pt (Gil et al., 2001).

The major drawbacks of traditional metal oxide supports, such as $\mathrm{Al}_{2} \mathrm{O}_{3}$, $\mathrm{SiO}_{2}$, zeolites, are: the low thermal conductivity - which causes sintering of supported-metal on hot spots of the support during deep and exothermic oxidation of VOCs (Yao et al., 1979), the reaction with water vapour at elevated temperatures and the vaporization of noble metals like oxychlorides (Völter et al., 1987). All these deficiencies cause the attempt of non-oxide materials as supports of catalyst used on catalytic oxidation of VOCs.

Pt supported on activated carbon have exhibited several advantages over the traditional $\mathrm{Pt} / \gamma-\mathrm{Al}_{2} \mathrm{O}_{3}$ (Wu et al., 2000) on VOCs oxidation, such as lower temperature for operation, a more hydrophobic surface, a more chlorine resistance and negligible metal-support interactions. But, activated carbon can not be used at temperature higher than $250^{\circ} \mathrm{C}$.

For hexagonal boron nitride (h-BN), a new non-oxide, with a lot of advantages like support (Niedenzu et al., 1965), the temperature is not a problem (Cofer and Econ, 1995). It has a high thermal stability against volatilization up to $800^{\circ} \mathrm{C}$ in air. $\mathrm{Pt}$ supported on $\mathrm{h}-\mathrm{BN}$ oxidizes more than $90 \%$ of gasoline vapour near to $200^{\circ} \mathrm{C}$ (Wu et al., 2001). In addition, this catalyst reported activities which can be maintained and endure longer than those of $\mathrm{Pt}-\mathrm{Al}_{2} \mathrm{O}_{3}$. "The use of h-BN will become a frontier in catalysis". 


\subsection{Active phases on total oxidation of VOCs}

There are two types of catalysts used in VOCs oxidation (GallardoAmores et al., 1998; Papaefthimiou et al., 1997; Zwinkels et al., 1993):

(i) noble metals and

(ii) oxides of transition metals.

By reviewing various aspects of the technology (Heck and Farrauto, 1995; Lahousse et al., 1998b) these have been considered the preferred catalysts.

Before discussing performances of each of them some notifications must be made. Firstly, it is important to know that VOCs compounds have different reactivity. The following order of reactivity was established (Hermia and Vigneron, 1993; O'Malley and Hodnett, 1999): alcohols $>$ aldehydes > aromatics $>$ ketones $>$ alkenes $>$ alkanes. Therefore for test the activity of a certain class of catalysts an alkane compound is a good choice (Spinicci et al., 2001) and probably this is the explanation for majority of studies which are made on $\mathrm{CH}_{4}$. Secondly, in practice the gas stream which must be treated consist in a mixture of organic compounds and that makes the choice of the right catalyst a big problem. It is reported that it is not easy to predict the mixture behaviour from the oxidation of single compound (Barresi and Baldi, 1993; Burgos et al., 2002; Hermia and Vigneron, 1993; Larsson and Andersson, 2000; Musialik-Piotrowska and Syczewska, 1989; Papaefthimiou et al., 1998; Yao and Kummer, 1973; Yao, 1973) because the performance of a catalyst is affected by the mutual effects. Some authors have reported that when VOCs are in mixture inhibiting effects can occur (Botavina et al., 2001; Burgos et al., 2002; Ordóňez et al., 2002; Yao and Kummer, 1973; Yao, 1973). Other studies claim that some VOCs molecules can be activated when are in mixture with other molecules (Hermia and Vigneron, 1993; Musialik-Piotrowska and Syczewska, 1989; Neyestanaki et al., 2000; Völter et al., 1987;) and also selectivity changes could occur (Barresi and Baldi, 1993; Musialik-Piotrowska and Syczewska, 1989). Consequently, it is very important to understand all the factors which determine VOCs reactivity over oxidation catalysts.

\subsubsection{Noble metals like active phases for VOCs oxidation}

Noble metals are known like catalysts with high activities for oxidative removal of VOCs from gaseous stream. $\boldsymbol{P t}$ and $\boldsymbol{P} \boldsymbol{d}$ are the most commonly used in practice, due to their high intrinsic activity (Papaefthimiou et al., 1997). They

are frequently alloyed with other metals such as $\mathrm{Ru}, \mathrm{Rh}, \mathrm{Os}$ and $\mathrm{Ir}$ and supported on oxides $\left(\mathrm{Al}_{2} \mathrm{O}_{3}, \mathrm{SiO}_{2}\right)$ (Ordóňez et al., 2002; Vigneron et al., 1996). Because oxidation reactions occur very fast on noble metals these active phases represent only a fraction of percent of the catalyst.

The company Catalytica has published an extensive review of the literature prior to 1993 (Horsley, 1993). The activity of metal catalysts depends considerably on the nature of the organic compound. Noble metals are widely applied to gases containing hydrocarbons and oxygenated compounds. 
Concerning hydrocarbons, these metals (Pt, Pd, Rh) supported on alumina, silica and zeolites have intensively studied and successfully used (Guisnet et al., 1999; Zwinkels et al., 1993). Excepting for palladium in the case of methane, platinum is recognised to be the most active metal for hydrocarbons oxidation (Burch and Hayes, 1995; Kang et al., 1994). Information concerning the activities of noble metals for oxidation of halogenated hydrocarbons varies in the literature; Petrosius et al. (Petrosius et al., 1993) claimed that noble metals are not choices for this reaction because of their price and their sensitivity of $\mathrm{Cl}_{2}$ and $\mathrm{HCl}$. In the same year Windawi and Wyatt (Windawi and Wyatt, 1993) claimed that these catalysts have been successfully commercialized for destruction of halogenated compounds, because of their efficiencies, and there are reports which can advocate this affirmation (Lester, 1999; Müller et al., 1993; Petrosius et al., 1993; Spivey and Butt 1992; Windawi and Wyatt, 1993; van den Brink et al., 1998).

A shortlist of some of the studies made on VOCs oxidation with noble metals (Pt and Pd) like active phases is given in Table 1.

Pd is more sensitive to sulphur and lead compounds (Kang et al., 1994; Hegedus et al., 1979) than Pt. Moreover, once sulphur was removed from the gas stream, Pt has a quicker recovery (Beck and Sommers, 1995). It was found that when $\mathrm{Pt}$ or Pd is used for hydrocarbons oxidation the influence of sulphur is insignificant especially at high temperature (Beck and Sommers, 1995).

On contrary, on propane oxidation over $\mathrm{Pt} / \gamma \mathrm{Al}_{2} \mathrm{O}_{3}, \mathrm{SO}_{2}$ has exhibited a promoting effect (Burch et al., 1998; Ishikawa et al., 1994; Marecot et al., 1994a). The same effect was reported also on naphthalene conversion over Pd/HZSM-5 and over Pd-Pt/HZSM-5 (Kalantar Neyestanaki et al., 2000). The poisoned catalysts can be regenerated at $600-800^{\circ} \mathrm{C}$ (Ball and Stack, 1991; Beck and Sommers, 1995).

It is important to use a low concentration of noble metals in catalysts as feasible, because of the high cost and limited availability. That means the active metals must be kept at a high degree of dispersion. But, it is reported that at a given amount of platinum or palladium an optimum particle size exists (Marecot et al., 1994b). For example, for propane oxidation this optimum corresponds to a metallic dispersion near $20 \%$ on platinum and $50 \%$ on palladium, respectively. Some studies (Gandhi and Shelef, 1987; Garetto and Apesteguia, 2000; Hicks et al., 1991; Labalme et al., 1996; Marecot et al., 1994a; Papaefthimiou et al., 1998) claimed that oxidation of hydrocarbons proceeds rather on larger metal crystallites, oxidation being generally considered to be a structure-sensitive reaction, albeit there are some controversies in literature (Chin and Resasco, 1999). In recent works (Pliangos et al., 1997; Papaefthimiou et al., 1998; Garetto and Apesteguia, 2000) it was found that platinum interacts with the carrier affecting the performance of the catalyst. Some authors (Yao et al., 1979) have reported that these interactions bring a negative influence on the catalytic activity. 
Table 1. Overview of some studies made on VOCs oxidation with noble metals as catalysts

\begin{tabular}{|c|c|c|c|c|}
\hline \multirow{2}{*}{\multicolumn{3}{|c|}{ VOCs }} & \multicolumn{2}{|c|}{ CATALYSTS / REFERENCES } \\
\hline & & & $P t-C A T A L Y S T S$ & $P d-C A T A L Y S T S$ \\
\hline \multirow{13}{*}{ 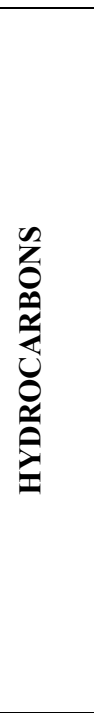 } & \multirow{6}{*}{ 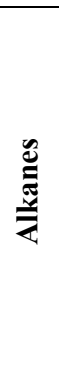 } & methane & $\begin{array}{l}\text { Bozo et al., 2000; - } \mathrm{CeO}_{2}-\mathrm{ZrO}_{2}{ }^{*} \text {. } \\
\text { Garetto and Apesteguia, } 2000 ;- \\
\mathrm{Al}_{2} \mathrm{O}_{3} \text {. }\end{array}$ & $\begin{array}{l}\text { Wang and Xie, } 2001 \mathrm{~b} ;- \\
\mathrm{SnO}_{2}\left(\mathrm{SO}_{4}^{2-}\right) .\end{array}$ \\
\hline & & propane & Marécot et al., 1994. & Marécot et al., 1994b. \\
\hline & & butane & Labalme et al., 1996. & \\
\hline & & heptane & Hicks et al., 1991. & \\
\hline & & cyclopentane & $\begin{array}{l}\text { Garetto and Apesteguia, 2000; - } \\
\mathrm{Al}_{2} \mathrm{O}_{3} \text {. }\end{array}$ & \\
\hline & & cyclohexane & & $\begin{array}{l}\text { Mochida et al., 1975. - } \\
\text { zeolite Y. }\end{array}$ \\
\hline & \multirow{4}{*}{ 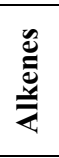 } & ethylene & \multicolumn{2}{|c|}{ Pliangos et al., $1997 ;-\mathrm{TiO}_{2}, \mathrm{ZrO}_{2}, \gamma-\mathrm{Al}_{2} \mathrm{O}_{3}, \mathrm{SiO}_{2}$} \\
\hline & & \multirow[t]{2}{*}{ propene } & Bozo et al., 2000; - $\mathrm{CeO}_{2}-\mathrm{ZrO}_{2}$. & \\
\hline & & & \multicolumn{2}{|c|}{ Marécot et al., 1994b. } \\
\hline & & cyclohexene & \multicolumn{2}{|c|}{ Kullavanijaya et al., $2000 ;-\mathrm{CeO}_{2}-\mathrm{Al}_{2} \mathrm{O}_{3}$. } \\
\hline & \multirow{3}{*}{ 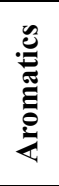 } & \multirow[t]{2}{*}{ benzene } & $\begin{array}{l}\text { Hermia and Vigneron, 1993; } \\
\text { Sawyer and Abraham, 1994; } \\
\text { Papaefthimiou et al., } 1998 .\end{array}$ & \\
\hline & & & \multicolumn{2}{|c|}{ Papaefthimiou et al., 1997.} \\
\hline & & toluene & Burgos et al., 2002; & Paulis et al. 2000; $-\mathrm{Al}_{2} \mathrm{O}_{3}$. \\
\hline \multirow{2}{*}{$\dot{0} \varrho^{n}$} & \multirow{2}{*}{\multicolumn{2}{|c|}{ trichloroethylene }} & van den Brink et al., 1998. & $\begin{array}{l}\text { Spivey and Butt, 1992; } \\
\text { Petrosius et al., } 1993 .\end{array}$ \\
\hline & & & \multicolumn{2}{|c|}{ Kulażyński et al., 2002; - $\mathrm{TiO}_{2}-\mathrm{SiO}_{2}$} \\
\hline \multirow{9}{*}{ 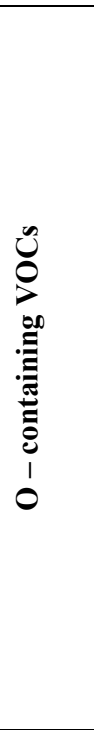 } & \multirow{3}{*}{$\frac{\frac{n}{e}}{\frac{e}{e}}$} & 2-propanol & Burgos et al., 2002; & \\
\hline & & $n$-butanol & $\begin{array}{l}\text { Sawyer and Abraham, 1994; } \\
\text { Hermia and Vigneron, } 1993 .\end{array}$ & \\
\hline & & & Papaefthimiou & 1., 1997. \\
\hline & $\stackrel{\mathscr{E}}{\Xi}$ & acetone & $\begin{array}{l}\text { Burgos et al., 2002; } \\
\text { Gil et al., 2001; - Al-pillared } \\
\text { smectite. }\end{array}$ & \\
\hline & $\stackrel{0}{\stackrel{0}{0}}$ & $\begin{array}{l}\text { methyl-ethyl- } \\
\text { cetone }\end{array}$ & $\begin{array}{l}\text { Gil et al., 2001; - Al-pillared } \\
\text { smectite. } \\
\text { Burgos et al., 2002. }\end{array}$ & \\
\hline & & ethyl-acetate & $\begin{array}{l}\text { Sawyer and Abraham, 1994; - } \\
\mathrm{Al}_{2} \mathrm{O}_{3} \text {. } \\
\text { Tichenor and Palazzolo, 1987; } \\
\text { Papaefthimiou et al., 1997. }\end{array}$ & \\
\hline & 远 & & Papaefthimiou & 1., 1997. \\
\hline & & $n$-butylacetate & & $\begin{array}{l}\text { Musialik-Piotrowska and } \\
\text { Syezewska, } 1989 .\end{array}$ \\
\hline & & $\begin{array}{l}\text { methyl- } \\
\text { methacrylate }\end{array}$ & Kullavanijaya et al., 2 & $-\mathrm{CeO}_{2}-\mathrm{Al}_{2} \mathrm{O}_{3}$ \\
\hline & & diethylamine & Kullavanijaya et al., 2 & $-\mathrm{CeO}_{2}-\mathrm{Al}_{2} \mathrm{O}_{3}$ \\
\hline 0 & & thiophene & Kullavanijaya et al., 2 & ; $\mathrm{CeO}_{2}-\mathrm{Al}_{2} \mathrm{O}_{3}$. \\
\hline 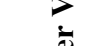 & & gasoline vapor & Wu et al., 2001; - h-BN. & \\
\hline$\stackrel{\mathscr{E}}{E}$ & & other VOCs & $\begin{array}{l}\text { O'Malley and Hodnett, 1999; - } \\
\text { mordenite, silica, alumina. }\end{array}$ & $\begin{array}{l}\text { Burck et al., 1995; - } \\
\qquad \mathrm{Al}_{2} \mathrm{O}_{3} . \\
\end{array}$ \\
\hline
\end{tabular}


Concerning the thermal resistance, Pd was said to be more resistant to thermal sintering in an oxidizing environment than Pt (Heck and Farrauto, 1995; Hegedus et al., 1979; Spivey and Butt, 1992). Pt volatilizes under oxidizing conditions (Gandhi and Shelef, 1987). Pd can be dispersed as oxides on $\mathrm{Al}_{2} \mathrm{O}_{3}$ at higher temperature $\left(750-850^{\circ} \mathrm{C}\right)$ than does $\mathrm{Pt}$ (Kummer, 1986). The interaction between $\mathrm{PdO}$ and $\mathrm{Al}_{2} \mathrm{O}_{3}$ gives considerable activity to $\mathrm{Pd}-\mathrm{Al}_{2} \mathrm{O}_{3}$ catalysts in an oxidising atmosphere. The oxides of $\mathrm{Pt}$ and $\mathrm{Pd}$ formed during the process are not as volatile in contrast to $\mathrm{RuO}_{2}, \mathrm{OsO}_{4}$ or $\mathrm{Ir}_{2} \mathrm{O}_{3}$ which are also poisonous (Cotton and Wilkinson, 1988).

In spite of their high activities, because of the cost, limited availability and sensitivity to high temperature and poisoning, researchers have been motivated to try the substitution of noble metals and the materials tried as catalysts for VOCs oxidation are: supported transition metals, oxides (simple, complex and combined) of these metals and combination noble metals-metal oxides.

\subsubsection{Transition metals like active phases on VOCs oxidation}

Several studies have been carried out in order to investigate transition metals supported on different materials on VOCs oxidation. A shortlist of suchlike studies is given in Table 2 .

Until recently, because of its chemical inertness (Schwank, 1983) and the difficulty to obtain a high dispersion on common support materials, gold was considered as one of the least catalytically used transition metal. In the last decade nanoparticles of gold, dispersed on metal-oxides such as $\mathrm{Fe}_{2} \mathrm{O}_{3}, \mathrm{Co}_{3} \mathrm{O}_{4}$ and $\mathrm{Mn}_{2} \mathrm{O}_{3}$, have been managed (Centeno et al., 2002) with a high catalytic activity on VOCs oxidation. When all the metals of the I B group supported on $\mathrm{Fe}_{2} \mathrm{O}_{3}$ (Scirè et al., 2001) were studied on oxidation of VOCs the following order of the catalytic activity was established: $\boldsymbol{A} \boldsymbol{u} / \mathrm{Fe}_{2} \mathrm{O}_{3} \gg \boldsymbol{A g} / \mathrm{Fe}_{2} \mathrm{O}_{3}>\boldsymbol{C} \boldsymbol{u} / \mathrm{Fe}_{2} \mathrm{O}_{3}>$ $\mathrm{Fe}_{2} \mathrm{O}_{3}$. It was found that $\mathrm{Au} / \mathrm{Co}_{3} \mathrm{O}_{4}(5 \% \mathrm{Au})$ is 70 times more active than $(0,5 \%)$ $\mathrm{Pt} / \mathrm{Al}_{2} \mathrm{O}_{3}$ on oxidation of $\mathrm{CH}_{2} \mathrm{Cl}_{2}$ (Chen et al, 1996), without any noticeable deactivation.

In the last decade transition metals exchanged or impregnated zeolites have been investigated on VOCs oxidation. It has found that transition metal cations increase the zeolite acidity and oxygen chemisorption thus improving the zeolite activity for hydrocarbons conversion (Chatterjee et al., 1992). Metal loaded zeolites (e.g. $\boldsymbol{C o}$-Y, $\boldsymbol{C r}$-Y, $\boldsymbol{C r}$-ZSM-5) were also studied on chlorinated compounds oxidation (Kiebling et al., 1998).

\subsubsection{Metal oxides like active phases on VOCs oxidation}

Metal oxides are an alternative to noble metals as catalysts for VOCs oxidation, although they can have the same catalytic activity but at higher temperature. The most active oxides have a $p$-semiconductor nature and the most frequently used ones are the oxides of $\mathrm{Ag}, \mathrm{V}, \mathrm{Cr}, \mathrm{Mn}, \mathrm{Fe}, \mathrm{Co}$. 
Table 2. Overview of some studies made on VOCs oxidation with transition metals like catalysts

\begin{tabular}{|c|c|c|c|c|}
\hline \multicolumn{3}{|c|}{ VOCs } & CATALYSTS & REFERENCES \\
\hline \multirow{10}{*}{ 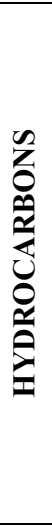 } & \multirow[t]{2}{*}{ alkanes } & \multirow[t]{2}{*}{$n$-hexane } & $\begin{array}{l}\mathrm{Au} / \mathrm{CeO}_{2} / \mathrm{Al}_{2} \mathrm{O}_{3} \text { and } \\
\mathrm{Au} / \mathrm{Al}_{2} \mathrm{O}_{3}\end{array}$ & Centeno et al., 2002. \\
\hline & & & Group VIII/support & $\begin{array}{l}\text { Papaefthimiou et al., 1997; } \\
\text { Lahousse et al., 1998b. }\end{array}$ \\
\hline & \multirow{7}{*}{ 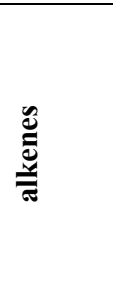 } & \multirow[t]{3}{*}{ benzene } & $\begin{array}{l}\mathrm{Au} / \mathrm{CeO}_{2} / \mathrm{Al}_{2} \mathrm{O}_{3} \text { and } \\
\mathrm{Au} / \mathrm{Al}_{2} \mathrm{O}_{3}\end{array}$ & Centeno et al., 2002. \\
\hline & & & $\mathrm{CuY}$ & Papaefthimiou et al., 1997. \\
\hline & & & Group VIII/support & Lahousse et al., 1998b. \\
\hline & & \multirow[t]{4}{*}{ toluene } & $\mathrm{Cr} ; \mathrm{Co} ; \mathrm{Cu} ; \mathrm{Ni} / \mathrm{Y}$ zeolite & Antunes, 1999. \\
\hline & & & $\mathrm{Au} / \mathrm{Fe}_{2} \mathrm{O}_{3}$ & Minicò et al., 2001. \\
\hline & & & $\mathrm{Au}(\mathrm{Ag}, \mathrm{Cu}) / \mathrm{Fe}_{2} \mathrm{O}_{3}$ & Scirè et al., 2001. \\
\hline & & & $\mathrm{CuNaHY}$ & Antunes et al., 2001. \\
\hline & \multicolumn{2}{|c|}{ other hydrocarbons } & Transition metals/zeolite & $\begin{array}{l}\text { Chatterjee et al., } 1992 . \\
\text { Neyerstanaki et al., } 1995 .\end{array}$ \\
\hline \multirow{7}{*}{$\begin{array}{l}\bigcup_{0}^{\infty} \\
1 \\
1 \\
0\end{array}$} & \multirow{7}{*}{$\frac{\frac{n}{e}}{\frac{e}{0}}$} & \multirow[t]{2}{*}{ methanol } & $\mathrm{Au} / \mathrm{Fe}_{2} \mathrm{O}_{3}$ & Minicò et al., 2001. \\
\hline & & & $\mathrm{Au}(\mathrm{Ag}, \mathrm{Cu}) / \mathrm{Fe}_{2} \mathrm{O}_{3}$ & Scirè et al., 2001. \\
\hline & & ethanol & $\mathrm{Au} / \mathrm{Fe}_{2} \mathrm{O}_{3}$ & Minicò et al., 2001. \\
\hline & & \multirow[t]{3}{*}{ 2-propanol } & $\begin{array}{l}\mathrm{Au} / \mathrm{CeO}_{2} / \mathrm{Al}_{2} \mathrm{O}_{3} \text { and } \\
\mathrm{Au} / \mathrm{Al}_{2} \mathrm{O}_{3}\end{array}$ & Centeno et al., 2002. \\
\hline & & & $\mathrm{Au} / \mathrm{Fe}_{2} \mathrm{O}_{3}$ & Minicò et al., 2001. \\
\hline & & & $\mathrm{Au}(\mathrm{Ag}, \mathrm{Cu}) / \mathrm{Fe}_{2} \mathrm{O}_{3}$ & Scirè et al., 2001. \\
\hline & & butanol & Group VIII/support & $\begin{array}{l}\text { Papaefthimiou et al., 1997; } \\
\text { Lahousse et al., 1998b. }\end{array}$ \\
\hline \multirow{5}{*}{$\begin{array}{l}0 \\
0 \\
1 \\
0\end{array}$} & \multirow{5}{*}{ 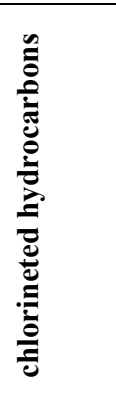 } & \multirow{2}{*}{$\begin{array}{l}\text { methylene } \\
\text { cloride }\end{array}$} & $\mathrm{CuCl}$ & Lago et al., 1996. \\
\hline & & & $\mathrm{Au} / \mathrm{Co}_{3} \mathrm{O}_{4}$ & Chen et al., 1996. \\
\hline & & \multirow[t]{2}{*}{ chlorobenzene } & $\begin{array}{l}\mathrm{Cr} / \text { doped pillared } \\
\text { bentonite clays }\end{array}$ & Storaro et al., 1995. \\
\hline & & & Uranium based catalyst & Hutchings et al., 1996. \\
\hline & & $\begin{array}{l}\text { chlorinated } \\
\text { hydrocarbons }\end{array}$ & Co-Y, Cr-Y, Cr-ZSM-5 & $\begin{array}{l}\text { Greene et al., 1996; } \\
\text { Ramachandran et al., 1996; } \\
\text { Chintawar and Green, } \\
1997 .\end{array}$ \\
\hline \multirow{2}{*}{\multicolumn{2}{|c|}{ O-VOCs }} & acetone & $\mathrm{Au} / \mathrm{Fe}_{2} \mathrm{O}_{3}$ & Minicò et al., 2001. \\
\hline & & ethylacetate & Group VIII/support & $\begin{array}{l}\text { Papaefthimiou et al., 1997; } \\
\text { Lahousse et al., 1998b. }\end{array}$ \\
\hline \multirow{3}{*}{\multicolumn{3}{|c|}{ other VOCs }} & $\mathrm{Au} /$ support & $\begin{array}{l}\text { Bond and Thompson, 1999; } \\
\text { Sakurai and Haruta, } 1995 .\end{array}$ \\
\hline & & & $\mathrm{Au} / \mathrm{Fe}_{2} \mathrm{O}_{3}$ & Minicò et al., 2000. \\
\hline & & & $\mathrm{Au}$ & Centeno et al., 2002. \\
\hline
\end{tabular}

Ni and $\boldsymbol{C u}$ (Pradier et al., 2000). Some combinations of oxides have exhibited higher activities as compared to single components or even comparable with that of a noble metal. Such catalysts include $\boldsymbol{C u}-\boldsymbol{M n}$ (Mehandjiev et al., 2000), $\boldsymbol{C u}$ - $\boldsymbol{C r}$ (Vass and Georgescu, 1996), $\boldsymbol{C u} \boldsymbol{V} \boldsymbol{V}$ (Ahlström and Odenbrand, 1990), $\boldsymbol{M n}-\boldsymbol{N i}$ (Mehandjiev et al., 1998), $\boldsymbol{A g}-\boldsymbol{M n}$ (Luo et al., 1998), Ag-Co (Luo et al., 1998), Cr-Co (Vass and Georgescu, 1996) Co-Zn 
(Klissurski and Uzunova, 1993), and $\boldsymbol{C} \boldsymbol{u}-\boldsymbol{A} \boldsymbol{l}$ (Peiyan et al., 1987). The perovskites, an interesting structural combination between cations and species of oxygen, are also, interesting like active species on VOCs oxidation. Their performances are discussed later. Transition metal oxides have been found to be very active, both in complete and selective oxidation of hydrocarbons (Anderson, 1986). Several mixed metal oxide systems were applied (Spivey and Butt, 1992; Zwinkels et al., 1993; Petrosius et al., 1993; Wilde and Anders, 1994; Kulazynski et al., 2002) on the oxidation of chlorinated hydrocarbons. Formation of toxic polychlorinated by-products (Froeze and Hutzinger, 1996) and loss of catalytic material as volatile oxychlorides (Griesbaum et al., 1997) are often encountered as drawbacks. An exception seems to be uranium oxide (Hutchings et al., 1996). A shortlist of some of the studies made on VOCs oxidation with metal oxides like active phases on VOCs oxidation is given in Table 3. Among the oxides mentioned in the literature, a few seems particularly promising as follows.

Table 3. Overview of some studies made on VOCs oxidation with transition metal oxides like catalysts

\begin{tabular}{|c|c|c|c|c|}
\hline \multicolumn{3}{|c|}{ VOCs } & CATALYSTS & REFERENCES \\
\hline \multirow{17}{*}{ 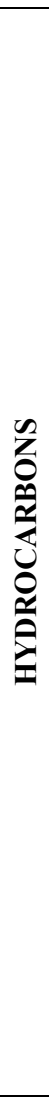 } & \multirow{5}{*}{ 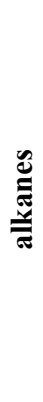 } & \multirow[t]{2}{*}{ methane } & \multicolumn{2}{|c|}{\begin{tabular}{l|l}
$\begin{array}{l}\text { Mn-based } \\
\text { oxides }\end{array}$ & $\begin{array}{l}\text { Zhang et al., 1989; Ozkan et al., 1990; } \\
\text { Lahousse et al., 1997; Milellea et al., 1998; } \\
\text { Gallardo-Amores et al., 1999. }\end{array}$ \\
\end{tabular}} \\
\hline & & & and Xie, 2001d & $\begin{array}{l}\text { Vang and Xie, 2001a; Wang } \\
\text { g and Xie, 2001c. }\end{array}$ \\
\hline & & ethane & $\mathrm{Cr}_{2} \mathrm{O}_{3} / \gamma-\mathrm{Al}_{2} \mathrm{O}_{3} ; \mathrm{Co}_{3} \mathrm{O}_{4} / \gamma-\mathrm{Al}_{2} \mathrm{O}_{3}$ & Kang and Wan, 1994. \\
\hline & & propane & $\begin{array}{l}\mathrm{SnO}_{2}-\mathrm{La}, \mathrm{Pr}, \mathrm{Nd}, \mathrm{Sm}, \mathrm{Gd} \\
\mathrm{SnO}_{2}-\mathrm{Cr}\end{array}$ & Harrison et al., 1999. \\
\hline & & $n$-butane & $\begin{array}{l}\mathrm{V}_{2} \mathrm{O}_{5}, \mathrm{Nb}_{2} \mathrm{O}_{5}, \mathrm{TiO}_{2}, \mathrm{MoO}_{3}, \mathrm{WO}_{3}, \\
\mathrm{ZrO}_{2}, \mathrm{HfO}_{2}, \mathrm{Dy}_{2} \mathrm{O}_{3}, \mathrm{MnO}_{2}, \mathrm{Cr}_{2} \mathrm{O}_{3}, \\
\mathrm{CuO} \text { and } \mathrm{Co}_{3} \mathrm{O}_{4} .\end{array}$ & Pradier et al., 2000. \\
\hline & \multicolumn{2}{|c|}{ Alkenes } & $\mathrm{Mo}-\mathrm{Nb}_{2} \mathrm{O}_{5}$ & Thorsteinnson et al., 1978. \\
\hline & \multirow{6}{*}{ 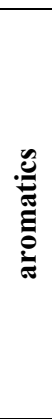 } & benzene & H-ZSM-5 & Anderson et al., 1991. \\
\hline & & toluene & $\mathrm{V}_{2} \mathrm{O}_{5} / \mathrm{Nb}_{2} \mathrm{O}_{5}$ & $\begin{array}{l}\text { Huuhtanen and Andersson, } \\
1993 .\end{array}$ \\
\hline & & & H-ZSM-5 & Dong et al., 1991. \\
\hline & & & $\mathrm{Co}_{3} \mathrm{O}_{4}-\mathrm{Sm}$ & Imamura, 1985. \\
\hline & & $\begin{array}{l}\text { methyl- } \\
\text { substituted } \\
\text { aromatic } \\
\text { compounds }\end{array}$ & $\mathrm{V}_{2} \mathrm{O}_{5}-\mathrm{Nb}_{2} \mathrm{O}_{5}$ & Sharipov et al., 1972. \\
\hline & & phenanthrene & Mn-Zr mixed oxides & $\begin{array}{l}\text { Fernández López et al., } \\
2001 .\end{array}$ \\
\hline & \multirow{5}{*}{\multicolumn{2}{|c|}{$\begin{array}{c}\text { other } \\
\text { hydrocarbons }\end{array}$}} & $\mathrm{ZrO}_{2}-\mathrm{CeO}_{2}$ & Terribile et al., 1999. \\
\hline & & & $\mathrm{SnO}-\mathrm{Cr}_{2} \mathrm{O}_{3}$ & $\begin{array}{l}\text { Fabritchnyl et al., 1992; } \\
\text { Harrison et al., } 1999 .\end{array}$ \\
\hline & & & $\mathrm{SnO}_{2}-\mathrm{Cu}, \mathrm{Pd}, \mathrm{Cr}, \mathrm{Sb}$ & Harrison, 1989. \\
\hline & & & $\mathrm{NiO}$ & Yao and Kummer, 1973. \\
\hline & & & $\alpha-\mathrm{Cr}_{2} \mathrm{O}_{3}$ & Yao, 1973. \\
\hline
\end{tabular}


Table 3 (continued)

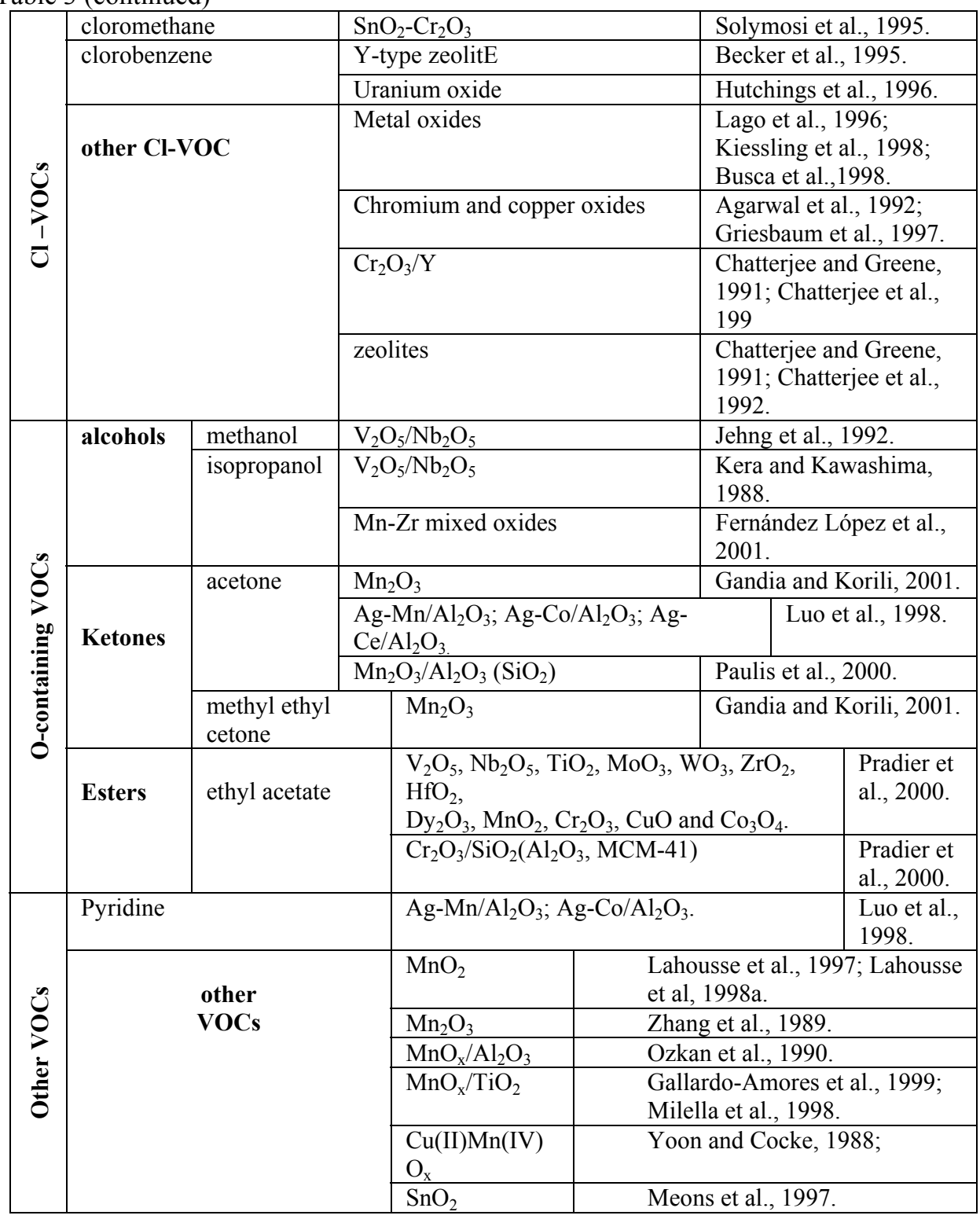

Chromium oxide containing catalysts (typically 12-25wt. \% chromia calculated as $\mathrm{Cr}_{2} \mathrm{O}_{3}$ ) seem to have been used broadly and successfully on halogenated compounds destruction (Lester, 1999; Petrosius et al., 1993) and are claimed to be ones of the most active catalysts in destruction of these compounds (Feijen-Jeurissen et al., 1999). The performances of some chromiabased catalysts seem to be superior to noble metals containing catalysts. But, at elevated temperature highly toxic volatile chromium oxychloride $\left(\mathrm{Cr}_{2} \mathrm{O}_{2} \mathrm{Cl}_{2}\right)$ is formed. This is a reason to restrict the application of Cr-based catalysts to low operation temperatures (Kulazynski et al., 2002). 
It was reported that the presence of water can inhibit this unwanted process (Lester, 1999).

Manganese oxides are recognized as being very active for total oxidation of CO and HCs (Zaki et al., 1999; van de Kleut, 1994;) and they are considered to be environment-friendly materials (Reidies, 1986).

According to Zener (Zener 1951), Mn oxides suchlike $\beta-\mathrm{MnO}_{2}, \gamma-\mathrm{MnO}_{2}$, $\mathrm{Mn}_{5} \mathrm{O}_{8}, \alpha-\mathrm{Mn}_{2} \mathrm{O}_{3}, \gamma-\mathrm{Mn}_{2} \mathrm{O}_{3}$ and $\alpha-\mathrm{Mn}_{3} \mathrm{O}_{4}$ are optimal surface redox catalysts. In a recent paper (Lahousse et al., 1998a), C. Lahousse et al. have reported that nsutite $(\gamma)$ form of $\mathrm{MnO}_{2}$ is more active on VOCs oxidation and in many respects superior to conventional catalysts based on noble metals. By addition of sodium and cesium ions into the structure of $\mathrm{Mn}_{2} \mathrm{O}_{3}$ (Gandia and Korili, 2001) it was found that its performance on acetone and methyl-ethyl-cetone combustion was improved; in contrast, sulfate ions decrease the activity of $\mathrm{Mn}_{2} \mathrm{O}_{3}$ and citric acid exhibits no influence.

According to some authors (Moles, 2001), to have Mn-based catalysts very active for oxidation, is needed tetravalent Mn. But, Mn (IV) compounds are usually unstable at high temperature and suffer decomposition to oxygen and less oxidized Mn compounds. Thus, researchers have attempted to stabilize this cation in different compositions analyzed then on VOCs oxidation. Some of them are the following. Mn (IV) stabilized into titania was found to not be very active (Milella et al., 1998). Mn-containing strontium titanate-zirconate perovsites have obtained good results on methane combustion (Daturi et al., 1997); zirconia, well known like good support for metals (Fuji et al., 1987) and oxides (Murakami et al., 1998), stabilizes Mn(IV) cations; several Mn-Zr mixed oxides (Fernández López et al., 2001) oxidize total phenanthrene, as a model for soot (pollutant present in diesel engine waste gases) at quite low temperatures $\left(250-400^{\circ} \mathrm{C}\right)$ and are very active and more selective to $\mathrm{CO}_{2}$ on isopropanol oxidation. These materials approach the catalytic activity of pure Mn oxides, but have a higher thermal stability and are more active than Mn-Ti catalysts. Mn-Fe composite oxides have higher activity than precious metal catalyst (Luo et al., 1993) on oxygen-containing organic compounds oxidation. Copper manganate and hopcalite (a mixture of copper (II) and manganese (IV) oxide have exhibited excellent properties like catalysts for post-combustion of model pollutants in wet air (Yoon and Cocke, 1988).

Compared with other metal oxides, for example $\mathrm{CuO}, \mathrm{Mn}$ oxides react to a lower extent with $\mathrm{Al}_{2} \mathrm{O}_{3}$ (Strohmeier and Hercules, 1984) to form spinel aluminate, $\mathrm{MnAl}_{2} \mathrm{O}_{4}$, of low activity, and at high temperatures, in presence of steam, present a lower volatility (van de Kleut, 1994). All the above results showed the potential applications of manganese oxides as catalysts for VOCs oxidation. Commercial catalysts based on oxides of $\mathrm{Mn}$ are available. They are used in self-cleaning oven walls (Tsyrulnikov et al., 1998).

$\boldsymbol{C u} \boldsymbol{O}$, a well known component of oxidation catalysts (Park and Ledford, 1998), has exhibited high activity in VOCs emission control applications. $\mathrm{CuO} / \mathrm{TiO}_{2}$ was found to be more active than oxides of $\mathrm{Fe}, \mathrm{Co}$ and $\mathrm{Mn}$ on toluene oxidation (Larsson et al., 1996). 
$\mathrm{CuO}$ has tolerance to sulphur (Peiyan et al., 1987). Due to its high activity, tolerance to sulphur and refractory nature (Prasad et al., 1984), CuO based catalysts have been considered as substitutes for noble metal catalysts in VOCs control.

It was found that both pure and modified $\mathbf{S n O}_{2}$ are active oxidation catalysts (Meons et al., 1997). The redox catalytic properties of tin (IV) oxide may be modified substantially by the incorporation of heteroelements (Harrison, 1989) such as copper, palladium, chromium and antimony (for the oxidation of carbon monoxide and hydrocarbons), phosphorus and bismuth (for oxidative coupling and oxidative dehydrogenation) and $\mathrm{Fe}, \mathrm{Cr}$ and $\mathrm{Mn}$ (for methane deep oxidation) (Wang and Xie, 2001a; Wang and Xie, 2001c; Wang and Xie, 2001d). Sn-Cr oxides display markedly improved activity for $\mathrm{CH}_{4}$ (Solymosi et al., 1995), hydrocarbons (Fabritchnyl et al., 1992) and for $\mathrm{CH}_{3} \mathrm{Cl}$ decomposition (Solymosi et al., 1995). The same catalysts proved resistance to $\mathrm{SO}_{2}$ and water deactivation. A good example of the impact of preparation technique of the performance of a catalyst is the most effective catalyst $\mathrm{Cr} / \mathrm{SnO}_{2}$, produced by impregnation of tin (IV) oxide gel using aqueous chromium (VI) oxide solutions at a $\mathrm{Cr}: \mathrm{Sn}$ ratio of 0,15 , that, as against a commercial $\mathrm{Pt} / \mathrm{Al}_{2} \mathrm{O}_{3}$ catalyst, exhibits significantly better activity toward propane oxidation (Harrison et al., 1999). Because the performances of chromium and copper-promoted tin (IV) oxides are similar to a $\mathrm{Pt} / \mathrm{Al}_{2} \mathrm{O}_{3}$ these are considered efficacious as three-way emission control catalysts (Harrison et al., 1998). It was reported that incorporation of rare earth cations such as $\mathrm{La}, \mathrm{Pr}, \mathrm{Nd}, \mathrm{Sm}, \mathrm{Gd}$ into tin (IV) oxide structure showed no significant enhancement of catalytic activity of $\mathrm{SnO}_{2}$ on propane oxidation (Harrison et al., 1999).

By mixing silver oxide with $\mathrm{Mn}$ oxide $\left(\mathrm{Ag}-\mathrm{Mn}(4: 1) / \mathrm{Al}_{2} \mathrm{O}_{3}\right)$, with cobalt oxide $\left(\mathrm{Ag}-\mathrm{Co}(4: 1) / \mathrm{Al}_{2} \mathrm{O}_{3}\right)$ or by addition of small amounts of cerium oxide on it are obtained catalysts with a higher activity than that of individual oxides for CO, acetone and pyridine oxidation (Luo et al., 1998).

$\boldsymbol{C o O}_{\boldsymbol{x}}$ is an efficient catalyst for total oxidation reactions (Luo et al., 1998; Ji et al., 2000). In addition it was found that oxides of cobalt can sorb sulphur and $\mathrm{CoAlO}_{4}$ is stable towards $\mathrm{SO}_{2}$.

Uranium oxide has been claimed to be an efficient and stable catalyst (Hutchings et al., 1996).

Niobium oxide, besides the role of the support, can be promoter (Luo et al., 1998). It enhanced the activity of molibdate catalyst for alkenes oxidation of vanadium oxide on methyl-substituted aromatic xylene and on o-xylene oxidation (Huuhtanen and Andersson, 1993).

The different roles and applications of ceria have been reviewed in several papers (Kašpar et al., 1999; Kummer, 1986; Trovarelli, 1996). Its nonstoichiometric structure (Harrisson et al., 1988), which allows the exchange oxygen with the environment, explains the promoting role of ceria. How ceria acts when it is added at noble metals and at metal oxides catalysts is reviewed by Ferrandon (Ferandon, 2001). Ceria is already used in three-way catalysts (Gandhi and Shelef, 1987; Kummer, 1986), diesel oxidation catalysts (Farrauto 
and Voss, 1996) and combustion catalysts (Groppi et al., 1999).

An interesting class of oxides is composed of perovskites. They are mixed oxides of general formula $\mathrm{ABO}_{3 \pm \delta}$, where $\mathrm{A}$ is usually a lanthanide and/or alkaline earth ion) and $\mathrm{B}$ is a transition metal ion (Forni and Rossetti, 2002). Many metals are stable in the $\mathrm{ABO}_{3}$ perovskite structure (Spinicci et al., 2001). By partially substitution of both $\mathrm{A}$ and $\mathrm{B}$, a wide variety of mixed oxides of general formula $\mathrm{A}_{1-\mathrm{x}} \mathrm{A}_{\mathrm{x}} \mathrm{B}_{1-\mathrm{y}} \mathrm{B}_{\mathrm{y}} \mathrm{O}_{3 \pm \delta}$ could be prepared. The last oxides, owing to their non-stoichiometry, indicated by the $\delta$ subscript in the formula, are characterized by structural and electronic defects. The cations A and B are responsible for catalytic activity in different ways (Islam et al., 1996; Leanza et al., 2000; Yamazoe and Teraoka, 1990).

Perovskites, due to their physicochemical and catalytic properties such as ionic conductivity, oxygen mobility within their lattice (Islam et al., 1996), oxygen sorption properties, great stability at high temperature (they are stable in a wide range of temperature, $25-1200^{\circ} \mathrm{C}$ ) and stabilization of unusual cation oxidation states in the structure (Tejuca and Fierro, 1992), were proposed as an attractive alternative to the very active noble metals oxidation catalysts (Forni and Rossetti, 2002).

A short list of some of the studies made on VOCs oxidation with perovskites like active phases is given in Table 4.

So far, perovskites have attracted great interest in hydrocarbons (Fierro, 1993; Tejuca and Fierro, 1992) and other volatile organic compounds (Lintz and Wittstock, 1996) oxidation. Three perovskites - $\mathrm{LaFeO}_{3}, \mathrm{LaCoO}_{3}$ and $\mathrm{LaMnO}_{3}$ were found to activate the $\mathrm{C}-\mathrm{H}$ bond cleavage of hexane better than $\mathrm{PdO} / \mathrm{Al}_{2} \mathrm{O}_{3}$ (Spinicci et al., 2001) and to be active on methane combustion (Ciambelli et al., 2001; Tejuca and Fierro, 1992). A catalytic activity comparable to that of $\mathrm{Pt} / \mathrm{Al}_{2} \mathrm{O}_{3}$ catalysts was reported for some perovskites studied on oxidation of methane (Zwinkels et al., 1993) and of chlorinated compounds (Sinquin et al., 1997). Concerning chlorinated compounds, they could be total oxidized by perovskites and in addition, the amounts of formed byproducts are significantly lower (Weber et al., 2001), but this process is connected with deactivation (Kiebling et al., 1998).

Because the preparation method of perovskites involves a high temperature heating step, perovskites have a low specific surface area $(<20$ $\mathrm{m}^{2} / \mathrm{g}$ ). To increase it and also, to increase the mechanical strength and the lifetime, this active phases are dispersed over refractory supports (e.g. $\gamma-\mathrm{Al}_{2} \mathrm{O}_{3}$, MgO) (Zwinkels et al., 1999; Cimino et al., 2001). Dispersion on zirconia provides a significantly enhanced specific activity of perovskites (Fuji et al., 1987; Cimino et al., 2002), while on all of the other oxide supports a remarkable decrease of specific activity per unit mass of perovskite, particularly in the case of $\mathrm{Al}_{2} \mathrm{O}_{3}$ and $\mathrm{SiO}_{2}$ (Fuji et al., 1987). In addition, zirconia can be stabilized against sintering at high temperatures, by a variety of dopants (La, Si) (Franklin et al., 1991). 
Table 4. Overview of some studies made on VOCs oxidation with perovskites like catalysts

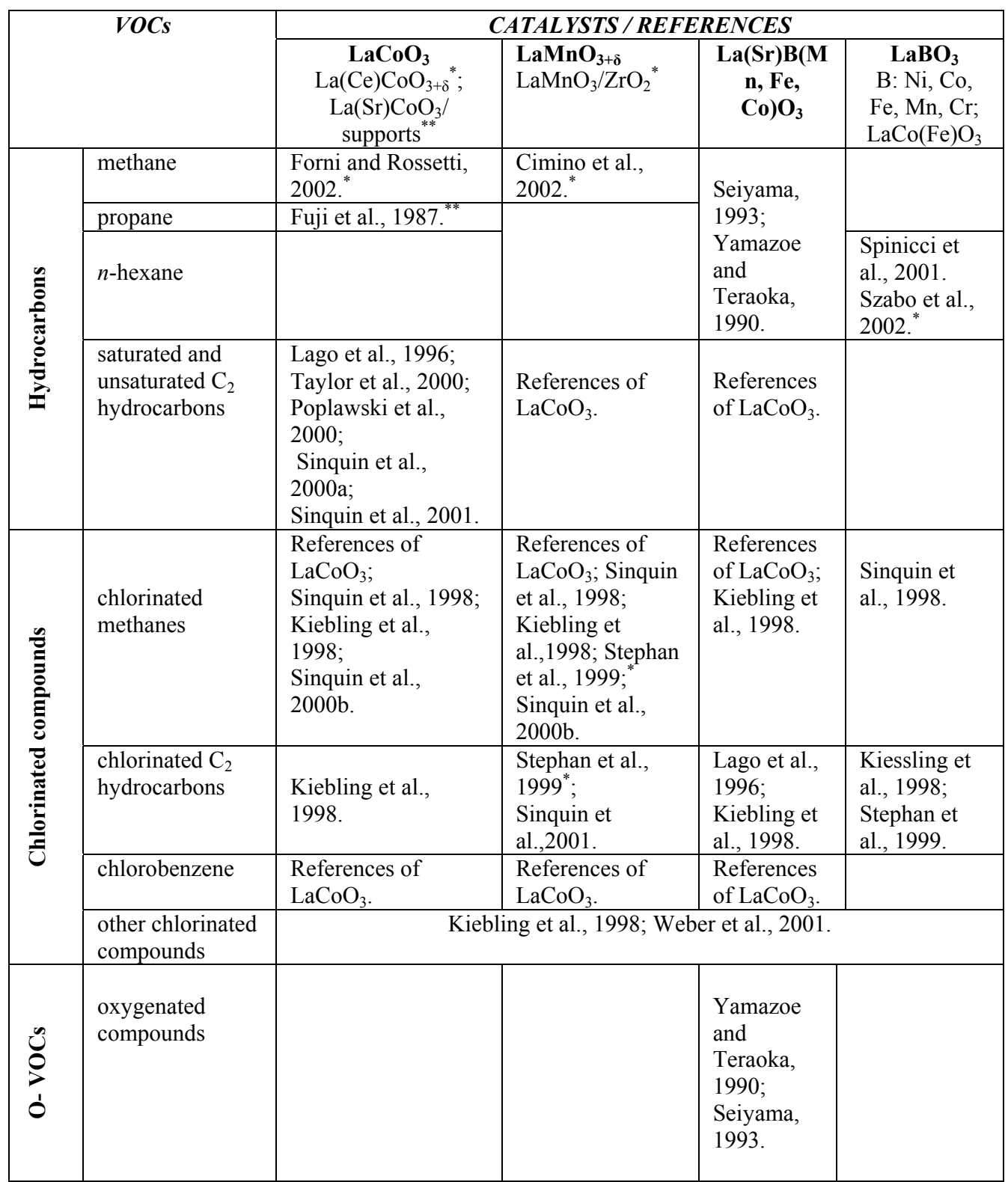

Recently, this major problem of perovskites (low specific surface area) was resolved by Kaliaguine et al. (Kaliaguine et al., 2001). The new technique of preparation involved is called "mechano-synthesis" and is performed at essentially room temperature. The samples obtained have surfaces area in excess of $100 \mathrm{~m}^{2} / \mathrm{g}$ and also, surface chemical properties of a particular interest. Another solution of the problem can be the synthesis of highly dispersed 
nanometre-size powders, obtainable by the" flame-hydrolysis technique" (Forni and Rossetti, 2002).

\subsubsection{Metal oxides versus noble metals. Their combinations like catalyst for VOCs oxidation}

Generally, metal oxides are more sensitive to sulphur than noble metals (Ball and Stack, 1991), but some metal oxides have exhibited a good sulphur resistance. In fact, the higher overall loading of metal oxides in the catalysts, that means a number of active sites orders of magnitude larger than that of noble metal catalysts, makes them more tolerant to poisons than noble metals (Hegedus et al., 1979). This above thing, combined with the higher thermal stability and the price incomparably good of the metal oxides (Spivey and Butt, 1992), and the higher specific activity of noble metals, are considered like different good properties by themselves. A good example that noble metals and metal oxides action different and complementary is the study (Kulazynski, 2002) made on trichloroethylene oxidation with $\mathrm{Cr}_{2} \mathrm{O}_{3}, \mathrm{~V}_{2} \mathrm{O}_{5}, \mathrm{Pt}$ and $\mathrm{Pd}$; the oxides, supported on $\mathrm{TiO}_{2}-\mathrm{SiO}_{2}$, have displayed a higher activity (expressed per weight) than noble metals, but noble metals are more stable and can be used under more heavy conditions (higher temperature and higher concentration of chlorine). All these things have persuaded researchers to mix these materials and analyze the mixtures on VOCs oxidation.

It has reported that noble metals and transition metal oxides enhance the activity each other mutually (synergism effect). Ferrandon have made a short review of these interactions (Ferrandon, 2001). Some examples of synergism are: doping $\mathrm{Pd}$ with oxides of $\mathrm{Co}$ or $\mathrm{Cr}$ it is restrained the poisoning effect of sulphur (Khairulin et al., 1997); by incorporation of Pt and Pd into metal oxides the selectivity toward $\mathrm{CO}_{2}$ is increased (Ménézo et al., 1993); the activity of $\mathrm{Pd}$ on $\mathrm{CH}_{4}$ oxidation is increased by addition of metal oxides, particularly oxides of Ni (Widjaja et al., 1999).

\section{Conclusions}

The general conclusion from this paper is that the catalysis, besides all its applications, could be a very good tool in the fight against the environment pollution with VOCs, as well.

By the lower temperatures involved for destruction of VOCs, a lot of advantages as against corresponding thermal options are provided, such as: attractive saved energy, longer equipment life and higher selectivity to $\mathrm{CO}_{2}$ and $\mathrm{H}_{2} \mathrm{O}$. In addition, in our days the limitations involved by the first catalysts used in this process are overcome or minimized. That is due to the aggressive research programme, developed by the catalyst suppliers. The new formulations of the catalysts allow for immunity to deactivators, for a higher thermal stability and a lower cost, as well. Thus, new doors, that could not have been considered a few years ago, have been opened.

In addition, operating a pilot system off of process slip streams and 
watching for trends, the optimization of the catalyst selection for the specific waste stream is allowed.

The catalytic oxidation, as an after treatment technology, provides an attractive combination of features.

\section{References}

Agarwal S.K., Spivey J.J., Butt J.B., (1992), Appl. Catal. A, 82, 259.

Ahlström A.F., Odenbrand C.U.I., (1990), Appl. Catal., A 60, 157-172.

Anderson J.R., Dong Q.-N., Chang Y.-F., Western R.J., (1991), J. Catal., 127, 113.

Anderson S.L.T., (1986), J. Catal., 98, 138.

Anguil Environmental Systems Inc., On line at: http://www.anguil.com.

Antunes A.P., Ribeiro M.F., Silva J.M., Ribeiro F.R., Magnoux P., Guisnet M., (2001), Appl. Catal. B: Environ., 33, 149-164.

Antunes A.P., Silva J.M., Ribeiro F.R., Ribeiro M.F., (1999), Book of Abstracts, $4^{\text {th }}$ European Congres son Catalysis, 712.

Auckland Regional Council, (2000), Performance Criteria for Air Pollution Control Equipment - Final, WI00180, On line at: http://www.arc.govt.nz/arc/library/i86069_2.PDF.

Avila P., Bahamonde A., Blanco J., Sánchez B., Cardona A.I., Romero M., (1998), Appl. Catal. B: Environ., 17, 75-88.

Ball D.J., Stack R.G., (1991), Catalysts for diesel powered vehicles, in Catalysis and Automotive Pollution Control II, Crucq A. (Ed.), Vol. 71. Elsevier, Amsterdam, 1991, p. 337.

Barresi A.A, Baldi G., (1993), Chem. Eng. Commun. 123, 31.

Bartholomew C.H., (1984), Chem. Ing., November 12, 96.

Beck D.D., Sommers J.W., (1995), Appl. Catal. B, 6, 185-200.

Becker L., Hatje U., Förster H., (1995), Stud. Surf. Sci. Catal., 94, 627.

Biloen P., Helle N., Verbeek H., Dautzenberg F.M., Sachtler W.M.H., (1977), J. Catal., 50, 77.

Bond G.C., Thompson D.T., (1999), Catal. Rev. Sci. Eng., 41, 319.

Botavina M.A., Nekrasov N.V., Kiperman S.L., (2001), Stud. Surf. Sci Catal., 135.

Bozo C., Garbowski E., Guilhaume N., Primet M., (2000), Stud. Surf. Sci. Catal., 130, 581-586.

Burch R., Halpin E., Hayes M., Ruth K., Sullivan J.A., (1998), Appl. Catal. B: Environmental, 19, 199-207.

Burch R., Hayes M.J., (1995), J. Mol. Cat., A 100, 13-33.

Burck R., Urbano F.I., Loader P.K., (1995), Appl. Catal. A: General, 123, 173.

Burgos N., Paulis M., Antxustegi M.M., Montes M., (2002), Appl. Catal. B: Environ. 38, 251-258.

Burtin P., Brunelle J.P., Pijolat M., Soustelle M., (1987), Appl. Catal., 34, 225-238.

Busca G., Baldi M., Pistarino C., Finocchio E., Berti F., Toledo G.P., (1998), Armor J.N., Extended Abstracts of 2nd World Congress on Environmental Catalysis, AICHE, Miami, 37.

Centeno M.A., Paulis M., Montes M., Odriozola J.A., (2002), Appl. Catal. A: Gen., 234, 65-78. 
Chatterjee S., Greene H.L., (1991), J. Catal., 130, 76.

Chatterjee S., Greene H.L., Park Y.J., (1992), J. Catal., 138, 179.

Chen B., Bai C., Cook R., Wright J., Wang C., (1996), Catal. Today, 30, 15.

Chin Y.-H., Resasco D.E., (1999), Catalytic oxidation of methane on supported palladium under lean conditions: kinetics, structure and properties, in Catalysis Bond G.C., Webb G. (Eds.), Vol. 14. The Royal Society of Chemistry, Cambridge.

Chintawar P.S., Greene H.L., (1997), J. Catal., 165, 12.

Ciambelli P., Cimino S., Lisi L., De Rosi S., Faticanti M., Minelli G., Porta P., (2001), Appl. Catal. B: Environ., 29(4), 239.

Cimino S., Pirone R., Lisi L., (2002), Appl. Catal. B: Environ., 35, 243-254.

Cimino S., Pirone R., Russo G., (2001), Ind. Eng. Chem. Res., 54.

Clean Air Counts, (2003), Low-VOC Paints, On line at: http://www.cleanaircounts.org/defaut.cfm?page $=$ strategies.

Cloud R.A., (1999), Choosing VOC control equipment, On line at: http://www.pfonline.com/articles/109903a.html.

Cofer C.G., Econ J., (1995), Carbon, 33(4), 389-395.

Cooley R., (2002), Burning Questions - Catalytic Oxidation $Q$ and A, Environmental Protection, On line at: www.alzeta.com/CATALYTIC_OXIDATION_COOLEY.pdf.

Cotton F.A., Wilkinson G. (Eds.), (1989), Advanced Inorganic Chemistry, $5^{\text {th }}$ ed. WileyInterscience, New-York, p. 880.

Daturi M., Busca G., Groppi G., Forzatti P., (1997), Appl. Catal. B: Environ., 12, 325.

Derouane E.G., (1985), Stud. Surf. Sci. Catal., 20, 221.

Dong Q.-N., Anderson J.R., Mole T., (1991), Appl. Catal., 72, 99.

Dumitriu E., Hulea V., (1997), Metode catalitice eterogene aplicate în protecția aerului, Edit. BIT, Iaşi.

Fabritchnyl P.B., Sudakova N.R., Berentsveig V.V., Demazeau G., Afanasov M.I., Etourneau J., (1992), J. Mater. Chem., 2, 763.

Farrauto R.J., Voss K.E., (1996), Appl. Catal. B, 10, 29-51.

Feijen-Jeurissen M.M.R., Jorna J.J., Nieuwenhuys B.E., Sinquin G., Petit C., Hindermann J.-P., (1999), Catal. Today, 54, 65-79.

Fernández López E., Sánchez Sscribano V., Resini C., Gallardo-Amores J.S., Busca G., (2001), Appl. Catal. B: Environ., 29, 251-261.

Ferrandon M., (2001), Mixed metal oxide-noble metal catalysts for total oxidation of volatile organic compounds and carbon monoxide, Department of Chemical Engineering and Technology, Chemical Reaction Engineering, Royal Institute of Technology, Stockholm.

Fierro J.L.G., (1993), Properties and Applications of Perovskite-type Oxides, Marcel Dekker, New York.

Forni L., Rossetti I., (2002), Appl. Catal. B: Environ., 38, 29-37.

Franklin R., Goulding P., Haviland J., Joyner R., McAlpine I., Moles P., Norman C., Nowell T., (1991), Catal Today, 10, 405.

Froeze K.L., Hutzinger O., (1996), Environm. Sci. Technol., 30, 1009.

Fuji H., Mizuno N., Misono M., (1987), Chem. Lett., 2147.

Galardo-Amores J.M., Armaroli T., Ramis G., Finocchio E., Busca G., (1999), Appl. Catal. B, 22, 249.

Gandhi H.S., Shelef M., (1987), The role of research in the development of new generation automotive catalysts, in Catalysis and Automotive Pollution Control, Crucq A., Frennet A.(Eds.), Vol. 30., Elsevier, Amsterdam, p. 199. 
Gandia L.M., Gil A., Korili S.A., (2001), Appl. Cata. B: Environm., 33, 1-8.

Garetto T.F., Apesteguia C.R., (2000), Catal. Today, 62, 189-199.

Gil A., del Castillo H.L., Masson J., Court J., Grange P., (1996), J. Mol. Catal. A, 107, 185.

Gil A., Vicente M.A., Lambert J.-F., Gandia L.M., (2001), Catal. Today, 68, 41.

Gil A., Vicente M.A., Toranzo R., Banares M.A., Gandia L.M., (1998), J. Chem. Technol. Biotechnol., 72, 131.

GlobalSpec Inc., (2003), Instrumentation and equipment used to control the properties and degree of purity of air, On line at: http://processequipment.globalspec.com/ProductFinder/Manufacturing_Process_Equipment/Ai $r$ Quality

Greene H.L., Prakash D.S., Athota K.V., (1996), Appl. Catal. B, 7, 213.

Griesbaum K., Hönicke D., Haas A., Schweerdtner F., Khemili A., (1997), Proceedings of the $213^{\text {th }}$ National Meting, Am. Chem. Soc., San Francisco, 175.

Groppi G., Cristiani C., Lietti L., Ramella C., Valentini M., Forzatti P., (1999), Catal. Today, 50, 399-412.

Guenther A., Hewitt C.N., Erickson C.D., Fall R., Geron C., Graedel T., Harley P., Klinger L., Lerdau M., McKay W.A., Pierce T., Scholes B., Steinbrecker R., Tallamraju R., Taylor J., Zimmerman R., (1995), J. Geophs. Res., 100, 8873.

Guisnet M., Dégé P., Magnoux P., (1999), Appl. Catal. B, 20, 1.

Harrison P.G., (1989), Chemistry of Tin, Harrison P.G. (Ed.), Chap. 12, Blackie, Glasgow.

Harrison P.G., Azelle W., Mubarak A.T., Bailey C., Daniell W., Lloyd N.C., (1998), Kruse N., Frennet A., Bastin J.-M., Catalysis and Automotive Pollution Control. IV. Studies in Surface Sience and Catalysis, vol. 116, Elsevier, Amsterdam.

Harrison P.G., Bailey C., Azelee W., (1999), J. Catal., 186, 147-159.

Haslego C.M.A., (2002), Report on Air Pollutin Control, On line at: http://www.cheresources.com/pollcontrolzz.shtml.

Heck R.M., Farrauto R.J., (1995), Catalytic Air Pollution Control, van Nostrand Reinhold, New York.

Hegedus L.L., Summers J.C., Schlatter J.C., Baron K., (1979), J. Catal., 56, 321-335.

Hermia J., Vigneron S., (1993), Catal. Today, 17, 349.

Hicks R.F., Lee R.G., Han W.J., Hook A.B., (1991), Structure-activity and Selectivity Relationship in Heterogeneous Catalysis, Graselli R.K., Sleight W. (Eds.), Elsevier, Amsterdam, p. 127.

Horsley J.A., (1993), Catalytica Environmental Report No E4, Catalytica Studies Division, Mountain View, CA, USA.

Hutchings G.J., Heneghan C.S., Hudson I.D., Taylor S.H., (1996), Nature, 384, 341.

Huuhtanen J., Andersson S.L.T., (1993), Appl. Catal. A: Gen., 98, 159-171.

Imamura S., Fukuda K., Nishida T., Inui T., (1985), J. Catal., 93, 186.

Ishikawa A., Komai S., Satsuma A., Hattori T., Murakami Y., (1994), Appl. Catal. A, 110, 61-66.

Islam M.S., Cherry M., Catlow C.R.A., (1996), J. Solid State Chem., 124, 230.

Ismagilov Z., Shkrabina R., Shikina N., Chistyachenko T., Ushakov V., Rudina N., (1998), Stud. Surf. Sci. Catal., 119, 83.

Iwamoto M., (1994), Stud. Surf. Sci. Catal., 84, 1395.

Ji L., Lin J., Zeng H.C., (2000), J. Phys. Chem. B, 104, 1783-1790.

John Zink Company, (1991), Innovations of catalytic combustion, International Symposium on environmental control of combustion processes, Honolulu. 
Kalantar Neyestanaki A., Lindfors L.E., Ollonqvist T., Väyrynen J., (2000), Appl. Catal. Gen. A., 196, 233-246.

Kaliaguine S., Van Neste A., Szabo V., Gallot J.E., Bassir M., Muzychuk R., (2001), Appl. Catal. A: Gen., 209, 345-358.

Kang S.K., Moon S.H., You I.S., Ha Y.O., (1994), The study of the characteristics of low temperature catalytic combustion and sulfur poisoning of noble metals, in Proceedings of International Workshop on Catalytic Combustion, Tokyo, 1994, (Arai H. Ed.), Catalysis Society of Japan, Tokyo, p. 10.

Kang Y.-M., Wan B.-Z., (1994), Appl. Catal. A, 114, 35.

Kera Y., Kawashima T., (1988), Bull. Chem. Soc. Jpn., 61, 1491.

Khairulin S., Béguin B., Garbowski E., Primet M., (1997), J. Chem. Soc. Faraday Trans., 93(12), 2217-2223.

Kiebling D., Schneider R., Kraak P., Haftendorn M., Wendt G., (1998), Appl. Catal. B: Environ., 19, 143-151.

Kiessling D., Schneider R., Kraak P., Haftendorn M., Wendt G., (1998), Appl. Catal. B, 19, 143.

Klissurski D., Uzunova E., Yankova K., (1993), Appl. Catal., A 95, 103-115.

Kucherov A.V., Slinkin A.A., Goryashenko S.S., Slovetskaya K.I., (1998), J. Catal., 118, 459.

Kühl G.H., (1999), Catalysis and Zeolites. Fundamentals and Applications, Weitkamp J. and Puppe L. (Eds.), 81, Springer-Verlag, Berlin.

Kulażyński M., Van Ommen J.G., Trwezynski J., Walendziewski J., (2002), Appl. Catal. B: Environ., 36, 239-247.

Kullavanijaya E., Trimm D.L., Cant N.W., (2000), Stud. Surf. Sci. Catal., 130A, 569574.

Kummer J.T., (1986), J. Phys. Chem., 90, 4747-4752.

Labalme V., Garbowski E., Ghilhaume N., Primet M., (1996), Appl. Catal. A, 138, 93.

Lago R.M., Green M.L.H., Tsang S.C., Odlyha M., (1996), Appl. Catal. B, 8, 107.

Lahousse C., Bernier A., Gaigneaux A., Ruiz P., Grange P., Delmon B., (1997), in Proceedings of the Third World Congres son Oxidation Catalysis, Grasselli R.K. et al. (Eds.), Elsevier, Amsterdam, p.777.

Lahousse C., Bernier A., Grange P., Delmon B., (1998a), J. Catal., 178, 214.

Lahousse C., Bernier A., Grange P., Delmon B., Papaefthimiou P., Ionnides T., Verykios X., (1998b), J. Catal., 178, 214.

Larsson P.-O., Andersson A., Wallenberg L.R., Svensson B., (1996), J. Catal., 163, 279293.

Leanza R., Rossetti I., Fabbrini L., Oliva C., Forn L., (2000), Appl. Catal. B: Environ., 28,55 .

Lester G.R., (1999), Catal. Today, 53, 407, and references there.

Lintz H.G., Wittstock K., (1996), Catal. Today, 29, 457.

Lintz H.-G., Wittstock K., (2001), Appl. Catal. A: Gen., 216, 217.

Luo M.-F., Yuan X.-X., Zheng X.-M., (1998), Appl. Catal. A: Gen., 175, 121-129.

Luo M.-F., Zhu B., Yuan X.-X., (1993), Chem World (Chinese), 34, 278.

Marecot P., El Idrissi D. El Azami Pirault L., Mabilon G. Prigent M., Barbier J., (1994a), Modification by sulfur of automotive exhaust catalysts: effects of the preparation procedure of the catalysts, in Catalyst Deactivation, Bartholomew C.H., Butt J.B. (Eds.), Vol. 88., Elsevier, Amsterdam, p. 343.

Marécot P., Fakche A., Kellali B., Mabilon G., Prigent M., Barbier J., (1994b), Appl. Catal. B, 3, 283-294. 
Mehandjiev D., Georgescu V., Cheshkova K., Ivanov, G., (2000), Catalytic activity of mixed alumina-supported $\mathrm{Cu}-\mathrm{Mn}$ oxides during complete oxidation of toxic organic compounds, in Heterogeneous Catalysis, Petrov L., Bonev Ch., Kadinov G. (Eds.), Proceedings of the $9^{\text {th }}$ International Symposium, Varna, Bulgaria, Institute of Catalysis, Bulgarian Academy of Sciences, Sofia, p 743.

Mehandjiev D., Zhecheva E., Ivanov G., Ioncheva R., (1998), Appl. Catal., A 167, 277 282.

Ménézo J.C., Rivière J., Barbier J., (1993), React. Kinet. Catal. Lett., 49(2), 293-298.

Meons L., Ruiz P., Delmon B., Devilers M., (1997), Catal. Lett., 46, 93.

Millela F., Gallardo-Amores J.M., Baldi M., Busca G., (1998), J. Mater. Chem., 8, 2525.

Minicò S., Scirè S., Crisafulli C., Galvagno S., (2001), Appl. Catal. B: Environ., 34, 277285.

Minicò S., Scirè S., Crisafulli C., Maggiore R., Galvagno S., (2000), Appl. Catal. B, 28, 245.

Minnesota Department of Health , (2003), Volatile Organic Compounds (VOCs) in your home, On line at: http://www.health.state.mn.us/divs/eh/indoorair/voc/.

Miyoshi N., Matsumoto S., Ozawa M., Kimura M., (1989), Development of thermal resistant three-way catalysts, SAE Paper, 891970.

Mochida I., Jitsumatsu T., Kato A., Seyiama T., (1975), J.Catal., 36, 361.

Moles P., (2001), Technical Report MEL Chemicals, On line at: http://www.zrchem.com.

Müller H., Deller K., Despeyroux B., Peldszus E., Kammerhofer P., Kuhn W., Spielmannleitner R., Stronger M., (1993), Catal. Today, 17, 383.

Murakami Y., Inomata M., Mori K., Uli T., Suzuki K., (1998), Preparation of Catalysts, Poncelet G., Grange P., Jacobs P.A. (Eds.), vol. III, Elsevier, Amsterdam, 531.

Musialik-Piotrowska A., Syezewska K., (1989), Environ. Protect. Eng., 15, 117.

Nakajima F., (1991), Catal. Today, 10, 1.

Neyestanaki A.K., Kumar N., Linfors L.-E., (1995), Appl. Catal. B, 7, 95.

Neyestanaki A.K., Lindfors L.-E., Ollonqvist T., Väyrynen J., (2000), Appl. Catal., A: Gen., 196, 233-246.

Nice K., (2003), How catalytic converters work, On line at: http://www.howstuffworks.com/catalytic-converter.htm.

Niedenzu K., Dawson J.W., (1965), Boron Nitride, Boron-Nitrogen Compounds, Springer, Berlin (Chapter 6).

O’Malley A., Hodnett B.K., (1999), Catal. Today, 54, 31-38.

Ordóňez S., Bello L., Sastre H., Rosal R., Diez V.F., (2002), Appl. Catal. B: Environ., 38, 139-149.

a Ozawa M., Toda H., Kato O., Suzuki S., (1996), Appl. Catal. B, 8, 123-140.

b Ozawa M., Toda H., Kato O., Suzuki S., (1996), Appl. Catal. B, 8, 141-155.

Ozkan U.S., Kueller R.F., Moctezuma E., (1990), Ind. Eng. Chem. Res., 29, 1136.

Papaefthimiou P., Ioanides T., Verykios X.E., (1997), Appl. Catal., 13, 175-184.

Papaefthimiou P., Ioanides T., Verykios X.E., (1998), Appl. Catal. B, 15, 75.

Park P.W., Ledford J.S., (1998), Appl. Catal. B, 15, 221-231.

Parkinson G., (1991), Chem. Eng., 37, 253.

Paulis M., Gandia L.M., Gil A., Sambeth J., Odriozola J.A., Montes M., (2000), Appl. Catal. B: Environ., 26, 37-46.

Peiyan L., Min W., Shaochun S., Minmin H., Jingfang R., Shomin Y., Hengxiang Y., Qiwu W., (1987), Development of non-noble metal catalysts for the purification of automotive exhaust gas, in Catalysis and Automotive Pollution Control, Crucq A., Frennet A. (Eds.),. Elsevier, Amsterdam, p. 395. 
Peiyan L., Weidong C., Shouming Y., (1995), J. Mol. Catal. (China), 9(3), 179-185.

Petrosius S.C., Drago R.S., Young V., Grunewald G.C., (1993), J. Am. Chem. Soc., 115, 6131.

Pliangos C., Yentekakis I.V., Papadakis V.G., Vayenas C.G., Verykios X.E., (1997), Appl. Catal. B: Environ., 14, 161-173.

Poplawski K., Lichtenberger J., Keil F.J., Schnitzlein K., Amiridis M.D., (2000), Catal. Today, 62, 329.

Pradier C.M., Rodriguez F., Marcus P., Landau M.V., Kaliya M.L., Gutman A., Herskowitz M., (2000), Appl. Catal. B: Environ., 27, 73-85.

Prasad R., Kennedy L.A., Ruckenstein E., (1984), Catal. Rev. Sci. Eng., 26, 1.

Ramachandran B., Greene H.L., Chatterjee S., (1996), Appl. Catal. B, 8, 157.

Regional Environmental Assessments, Inc., (2002), VOCs - Answers To Your Indoor Air Quality Concerns, On line at: http://www.reainc.us/voc.htm.

Reidies A.H., (1986), in Ullmann's Encyclopedia of Industrial Chemistry, Elvers B., Hawkins S., Schulz G. (Eds.), $5^{\text {th }}$ ed., Vol. A16. VCH, New York, p. 123.

Ron Joseph \& Associates, (2000), VOC definition in: Regulations, Violations, Permits, VOC, HAP and Such, On line at: http://www.ronjoseph.com/Q\&A/permits_q20.htm.

Sakurai H., Haruta M., (1995), Appl, Catal. A, 127, 93.

Sawyer J.E., Abraham M.A., (1994), Ind. Eng. Chem. Res., 33, 2084.

Schwank J., (1983), Gold. Bull., 16, 103.

Scirè S., Minicò S., Crisafulli C., Galvagno S., (2001), Catal. Communic., 2, 229-232.

Seiyama T., (1993), in: Tejuca L.G., Fierro J.L.G. (Eds.), Properties and Application of Perovskite-Type Oxides, Marcel Dekker, New York.

Sharipov A.K., Kirichenko Y.V., Masagutov R.M., Shabalin I.I., Maslennikova G.P., Sharipov B.G., (1972), Zhur, Prikl. Khim., 6, 1389.

Shkrabina R.A., Koryabkina N.A., Kirichenko O.A., Ushakov V.A., Kapteijn F., Ismagilov Z.R., (1995), Thermostability of copper-chromium oxide catalysts on alumina support promoted by lanthanum and cerium, in Preparation of Catalysts, Poncelet G. et al. (Eds.), VI, Elsevier, Amsterdam, p. 1145.

a Sinquin G., Hindermann J.P., Petit C., Kiennemann A., (2000), Catal. Today, 54, 107.

b Sinquin G., Petit C., Libs S., Hindermann J.P., Kiennemann A., (2000), Appl. Catal. B: Environ., 27, 105-115.

Sinquin G., Petit C., Hindermann J.P., Kiennemann A., (1997), Proceedings of the Europcat-3, Krakow, 462.

Sinquin G., Petit C., Hindermann J.P., Kiennemann A., (1998), in: Chemistry, Energy and the Environment, Sequeira C.A.C., Moffat J.B. (Eds.), , The Royal Society of Chemistry, p.153.

Sinquin G., Petit C., Libs S., Hindermann J.P., Kiennemann A., (2001), Appl. Catal. B: Environ., 32, 37-47.

Solymosi F., Rasko J., Papp E., Oszoko A., Bansagi T., (1995), Appl. Catal. A., 131, 55.

Spinicci R., Tofanari A., Faticanti M., Pettiti I., Porta P., (2001), J. Molec. Catal. A: Chemical, 176, 247-252.

Spivey J., Butt J., (1992), Catal. Today, 11(4), 465-500.

Stephan K., Hackenberger M., Kiessling D., Wendt G., (1999), Catal Today, 54, 23.

Storaro L., Ganzerla R., Lenarda M., Zanoni R., (1995), J. Mol. Catal. A, 97, 139.

Strohmeier B.R., Hercules D.M., (1984), J. Phys. Chem., 88, 4922-4929.

Süd-Chemie Prototech, PRO*HHC Halogenated Hydrocarbon Catalysts, On line at: http://prototech.sud-chemieinc.com/brochure_pro_hhc.shtml. 
Szabo V., Bassir M., Van Neste A., Kaliaguine S., (2002), Appl. Catal. B: Environ., 37, 175-180.

Taylor S.H., Henegham C.S., Hutchings G.J., Hudson I.D., (2000), Catal. Today, 59, 249.

Tejuca L.G., Fierro J.L.G. (Eds.), (1992), Properties and Application of Perovskite-Type Oxides, Marcel Dekker, New York.

Terribile D., Trovarelli A., de Leitenburg C., Primavera A., Dolcetti G., (1999), Catal Today, 47, 133.

Thomas J.M., Thomas W.J., (1967), Introduction to the principles of heterogeneous catalysis, Academic Press, New York.

Thorsteinnson E.M., Wilson T.P., Young F.G., Kasai P.H., (1978), J. Catal., 52, 116.

Tichenor B.A., Palazzolo M.A., (1987), Environ. Prog., 6, 172.

Trimm D.L., (1991), Thermal stability of catalyst supports, in Catalyst Deactivation, Bartholomew C.H., Butt J.B. (Eds.), Elsevier, Amsterdam, 1991, p. 29.

Trovarelli A., (1996), Catal. Rev. Sci. Eng., 38, 439.

Tsyrulnikov P.G., Kovalenko O.N., Gogin L.L., Starostina T.G., Noskov A.S., Kalinkin A.V., Krukova G.N., Tsybulya S.V., Kudrya E.N., Bubnov A.V., (1998), Appl. Catal., A 167, 31-37.

Tucci E.R., (1982), Hydrocarbon Processing, 159-166.

U.S. Environmental Protection Agency, (2003), Sources of Indoor Air Pollution Organic Gases, On line at: http://www.epa.gov/iaq/voc.html.

Uberoi M., (2000), Choosing the Right VOC Emission Control Technology, MEGTEC Systems, On line at: www.pfonline.com/articles/030002.html.

Van de Kleut D., (1994), On the preparation and properties of manganese oxide based combustion catalysts, $\mathrm{PhD}$ Thesis, University of Utrecht, The Netherlands.

Van den Brink R.W., Louw R., Mulder P., (1998), Appl. Catal. B: Environ., 16, 219.

Vass M.I., Georgescu V., (1996), Catal. Today, 29, 463-470.

Vehicle Certification Agency, (2002), Exhaust Emissions Testing, On line at: http://www.vcacarfueldata.org.uk/e emissions.htm.

Vigneron S., Deprelle P., Hermia J., (1996), Catal. Today, 27, 229.

Völter J., Lietz G., Spindler H., Lieske H., (1987), J. Catal., 104, 375-380.

a Wang X., Xie Y.-C., (2001), React. Kinet. Catal. Lett., 72 (2), 229-237.

b Wang X., Xie Y.-C., (2001), React. Kinet. Catal. Lett., 72, 115-123.

c Wang X., Xie Y.-C., (2001), Catal. Lett. 75 (1-2), 73-80.

d Wang X., Xie Y.-C., (2001), Appl. Catal. B: Environ., 35, 85-94.

Weber R.., Plinke M., Xu Z., Wilken M., (2001), Appl. Catal. B: Environ., 31, 195.

Widjaja H., Sekizawa K., Eguchi K., Arai H., (1999), Catal. Today, 47, 95-101.

Wilde M., Anders K., (1994), Chem. Technik, 46, 316.

Wilde M., Anders K., (1994), Chem. Technol., 46, 316.

Windawi H., Wyatt M., (1993), Platinum Metals Rev., 37, 186.

Wu J.C.-S., Lin Z.-A., Pan J.-W., Rei M.-H., (2001), Appl. Catal. A: Gen., 219, 117-124.

Wu J.C.S., Lin Z.A., Tsai F.M., Pan J.W., (2000), Catal. Today, 63, 419-426.

Yamazoe N.Y., Teraoka Y., (1990), Catal. Today, 8, 175.

Yao H.C., Sieg M., Plummer Jr. H.K., (1979), 59, 365-374.

Yao Y.F.Y., (1973), J. Catal., 28, 139.

Yao Y.F.Y., Kummer J.T., (1973), J. Catal., 28, 124.

Yoon C., Cocke D., (1988), J. Catal., 113, 267.

Zaki M.I., Hasan M.A., Pasupulety L., Fouad N.E., Knözinger H., (1999), New J. Chem., 23, 1197-1202. 
Zener, C., (1951), Phys. Rev., 81(4), 440-444.

Zhang H.M., Teraoka Y., Yamazoe N., (1989), Catal. Today, 6, 155.

Zwinkels M., Haussner O., Jaras S.G., Menon P.G., (1999), Catal. Today, 47, 11.

Zwinkels M.F.M., Järås S.G., Menon P.G., Griffin T.A., (1993), Catal. Rev.-Sci. Eng., 35, 319 . 